\title{
Pedoman Tatalaksana Dislipidemia PERKI 2013
}

\author{
Erwinanto, Anwar Santoso, Johannes NE Putranto, Pradana Tedjasukmana, Rurus \\ Suryawan, Sodiqur Rifqi, Sutomo Kasiman \\ Kelompok Keria Lipid Perhimpunan Dokter Spesialis Kardiovaskular Indonesia
}

\section{Prakata}

Pedoman tatalaksana ini merupakan pedoman tatalaksana dislipidemia pertama yang dibuat oleh PERKI. Tujuan pembuatan pedoman tatalaksana ini adalah untuk membantu dokter membuat keputusan dalam praktek sehari-hari. Pedoman inimenyarikan dan mengevaluasi bukti-bukti yang ada ketika pedoman tatalaksana ini dibuat. Isi dari pedoman tatalaksana ini mengacu terutama pada pedoman tatalaksana dislipidemia ESC/EAS tahun 2011 serta berbagai hasil penelitian lainnya. Keputusan akhir tentang terapi individual merupakan tanggung jawab dari dokter yang menangani pasien.

\section{li. Pendahuluan}

\section{I. Lingkup Masalah}

Penyakit kardiovaskular akibat aterosklerosis dinding pembuluh darah dan trombosis merupakan penyebab utama kematian didunia. ${ }^{1}$ Entitas klinis utama dari penyakit tersebut adalah PJK, stroke iskemik, dan penyakit arteri perifer. Penyebab penyakit tersebut bersifat multifaktorialdi mana sebagian diantaranya dapat dimodifikasi. Salah satu faktor risiko yang

\footnotetext{
Alamat Korespondensi

dr. Erwinanto, SpJP. Kelompok Kerja Lipid PERKI. E-mail: inaheart@ indosat.net.id
}

dapat dimodifikasi adalah dislipidemia. ${ }^{2-4}$ Terdapat hubungan yang kuat antara dislipidemia dan penyakit kardiovaskular yang relatif setara antara populasi Asia dan non-Asia di wilayah Asia Pasifik. ${ }^{5,6}$ Data di Indonesia berdasarkan Laporan Riskesdas Bidang Biomedis tahun 2007 menunjukkan bahwa prevalensi dislipidemia atas dasar konsentrasi kolesterol total $>200 \mathrm{mg} / \mathrm{dL}$ adalah 39,8\%. Beberapa propinsi di Indonesia seperti Nangroe Aceh, Sumatra Barat, Bangka Belitung dan Kepulauan Riau mempunyai prevalensi dislipidemia $\geq 50 \%$. ${ }^{7}$ Data prevalensi pada umumnya menggunakan data populasi negara barat atau negara di Asia. ${ }^{4,8}$ Mengingat hal di atas, tatalaksana dislipidemia harus dianggap sebagai bagian integral dari pencegahan penyakit kardiovaskular.

\section{2. Dislipidemia dan Penyakit Kardiovaskular}

Dislipidemia disebabkan oleh terganggunya metabolisme lipid akibat interaksi faktorgenetik dan faktor lingkungan. Walau terdapat bukti hubungan antara kolesterol total dengan kejadian kardiovaskular, hubungan ini dapat menyebabkan kesalahan interpretasi ditingkat individu seperti pada wanita yang sering mempunyai konsentrasikolesterol HDL yang tinggi. Kejadian serupa juga dapat ditemukan pada subjek denganDM atau sindrom metabolikdi manakonsentrasi kolesterol HDL sering ditemukan rendah. Pada keadaan ini, penilaian risiko hendaknya mengikutsertakan analisis berdasarkan konsentrasi kolesterol HDL dan LDL. 
Terdapat bukti kuat hubungan antara kolesterol LDLdengan kejadian kardiovaskular berdasarkan studi luaran klinis ${ }^{9}$ sehingga kolesterol LDL merupakan target utama dalam tatalaksana dislipidemia.Kolesterol HDL dapat memprediksi kejadian kardiovaskular bahkan pada pasien yang telah diterapi dengan statin ${ }^{10}$ tetapi studi klinis tentang hubungan peningkatan konsentrasi kolesterol HDL dengan proteksi kardiovaskular tidak meyakinkan. ${ }^{11-14}$ Bila target kolesterol LDL sudah tercapai, peningkatan kolesterol HDL tidak menurunkan risiko kardiovaskular berdasarkan studi klinis yang ada. ${ }^{13}$ Peran peningkatan konsentrasiTG sebagai prediktor terhadap penyakit kardiovaskular masih menjadi perdebatan. Hubungan antara TG puasa dengan risiko kardiovaskular yang didapat berdasarkan analisis univariat melemah setelah dilakukan penyesuaian terhadap faktor lain terutama kolesterol HDL. KonsentrasiTG yang tinggi sering disertai dengan konsentrasi kolesterol HDL rendah dan konsentrasismall,dense LDL yang tinggi sehingga diperkirakan pengaruh hipertrigliseridemia terhadap risiko kardiovaskular secara tidak langsung disebabkan oleh konsentrasi kolesterol HDL rendah dan konsentrasismall, dense LDL tinggi. ${ }^{15}$ Beberapa penelitian melaporkan konsentrasiTG tidak puasa memprediksi risiko penyakit kardiovaskular lebih baik dari konsentrasi puasa ${ }^{16,17}$ tetapi mengingat sampai saat ini masih diperdebatkan penggunaannya pada praktek klinis maka TG yang dipakai untuk prediksi kejadian kardiovaskular adalah TG yang diperiksa saat puasa.

Beberapa jenis dislipidemia campuran yang berhubungan dengan terbentuknya lipid aterogenik dapat menimbulkan penyakit kardiovaskular prematur. Termasuk disini adalah meningkatnyakolesterol VLDL yang dimanifestasikan dengan peningkatan TG, meningkatnya small, dense LDL, dan berkurangnya kolesterol HDL. Kolesterol VLDL berkorelasi tinggi dengan lipid aterogenik sehingga masuk akal untuk digunakan dalam memprediksi risiko kardiovaskular bersama dengan kolesterol LDL. Jumlah kolesterol LDL, VLDL, dan IDL disebut sebagai kolesterol non-HDL yang pada dasarnya adalah lipidyang mengandung apoB. Mengingat dalam praktek klinis kolesterol IDL masuk kedalam pengukuran kolesterol LDL maka konsentrasi kolesterol non-HDL besarnya sama dengan penjumlahan kolesterol VLDL dan LDL. Dalam prakteknya, kolesterol non-HDL dihitung dengan mengurangkan kolesterol HDL terhadap kolesterol total (Kolesterol non-HDL $=$ Kolesterol Total - Kolesterol HDL).Konsentrasi kolesterol non-
HDL berkorelasi kuat dengan konsentrasi apoB. Walau tidak ditujukan sebagai target terapi primer, berbagai studi luaran klinis memeriksa apoB bersama dengan kolesterol LDL. Berbagai studi prospektif menunjukkan apo B mampu memprediksi risiko kardiovaskular lebih baik dari kolesterol LDL terutama pada keadaan di mana terdapat hipertrigliseridemia yang menyertai DM, sindrom metabolik, dan PGK. ${ }^{18-21}$

Walau terdapat ketidakserasian hasil penelitian tentang kekuatan hubungan antara apoB dan kolesterol non-HDL dalam memprediksi penyakit kardiovaskular, ${ }^{18,22}$ kolesterol non-HDL dapat dianggap mewakili lipid aterogenik karena konsentrasinya berkorelasi baik dengan konsentrasi apoB. Pada saat ini belum ada penelitian yang menempatkan apoB atau kolesterol non-HDL sebagai target terapiprimer obat penurun lipid. Pada keadaan konsentrasiTG $<200$ mg/ dL, konsentrasi kolesterol VLDL pada umumnya tidak meningkat, sehingga kolesterol non-HDL diperkirakan hanya sedikit meningkatkan nilai prediksi penyakit kardiovaskular dibandingkan kolesterol LDL.Keadaan serupa juga terjadi jika konsentrasiTG serum $\geq 500$ $\mathrm{mg} / \mathrm{dL}$ di mana lipoprotein kaya TG lebih banyak berbentuk kolesterol VLDL berpartikel besar dan kilomikron yang non-aterogenik. Oleh karena itu, menggunakan kolesterol non-HDL untuk prediksi risiko penyakit kardiovaskular sebaiknya dilakukan pada konsentrasi TG 200-499 mg/dL. ${ }^{23}$

Berbagai rasio parameter lipid telah diteliti hubungannya dengan risiko kardiovaskular. Rasio kolesterol total/HDL dan rasio kolesterol nonHDL/HDL merupakan prediktor kuat untuk risiko kardiovaskular pada pasien DM. ${ }^{24}$ Rasio apoB/apoA1 juga mengindikasikan risiko kardiovaskular. ${ }^{6}$ Saat ini berbagai rasio tersebut digunakan untuk estimasi risiko kardiovaskular tetapi tidak digunakan untuk diagnosis dislipidemia maupun sebagai target terapi.

Lipoprotein(a) dibentuk oleh partikel kolesterol LDL yang berikatan dengan plasminogen-like glycoprotein bernama apolipoprotein(a). Lipoprotein(a) berperan dalam terjadinya infark miokard dan penyakit jantung iskemik melalui 2 mekanisme. Partikel kolesterol LDL yang dikandung di dalam Lp(a) menyebabkan proses aterosklerosis. Plasminogenlike glycoprotein dapat mengintervensi fibrinolisis dan meningkatkan risiko trombosis. Lipoprotein(a) berhubungan dengan penyakit kardiovaskular(PJK dan stroke) secara kontinu dan independen terhadap faktor risiko lain. Tingkat hubungannya sedang saja, sebesar 25\% kekuatan hubungan kolesterol non-HDL 
dengan penyakit kardiovaskular. ${ }^{25}$ Peningkatan Lp(a) mempunyai hubungan sebab-akibat dengan penyakit kardiovaskular prematur. ${ }^{26}$

Small, dense LDL, yang berhubungan dengan hipertrigliseridemia, adalah partikel lipid yang aterogenik. Peningkatan TG dalam kolesterol VLDL akan mengaktivasi CETP yang berakibat terjadinya pengayaan kolesterol LDL dan HDL dengan TG. Lipase TG hepar akan menghidrolisis TG dalam partikel kolesterol LDL dan HDL dan mengakibatkan terbentuknya partikel small, dense LDL dan HDL. Studi eksperimental menunjukkan bahwa kolesterol yang diperkaya oleh TG mengalami disfungsi. ${ }^{27,28}$ Partikel small, dense LDL mempunyai kerentanan tinggi terhadap oksidasi. ${ }^{29,30}$ Peningkatan partikel kolesterol LDL yang aterogenik terbukti meningkatkan risiko kardiovaskular ${ }^{31}$ tetapi saat ini belum ada penelitian klinis yang menunjukkan reduksi risiko kardiovaskular akibat penurunan jumlah partikel small, dense LDL melebihi reduksi risiko akibat penurunan konsentrasi kolesterol LDL.

\section{Evaluasi Laboratorium Parameter Lipid Dan Lipoprotein}

Rekomendasi profil lipid yang diperiksa secara rutin adalah kolesterol total, kolesterol LDL, kolesterol HDL, dan TG. Pemeriksaan parameter lain seperti apoB, apoA1, Lp(a), dan small, dense LDL tidak dianjurkan diperiksa secara rutin. Kolesterol LDL setidaknya dihitung dengan formula Friedewald (kecuali bila TG>400 $\mathrm{mg} / \mathrm{dL}$ atau dalam keadaan tidak puasa) karena sebagian besar studi klinis menggunakan formula Friedewald. Dengan formula Friedewald dapat diperhitungkan bahwa kolesterol LDL (dalam mg/ $\mathrm{dL})=$ kolesterol total-kolesterol HDL-TG/5.32 Jika memungkinkan, sampel darah diambil setelah puasa $12 \mathrm{jam}$. Hal ini hanya diperlukan untuk pemeriksaan TG yang juga dipakai untuk penghitungan konsentrasi kolesterol LDL memakai formula Friedewald. Kolesterol total dan HDL dapat diperiksa dalam keadaan tidak puasa. Pada keadaan di mana formula Friedewald tidak dapat digunakan (konsentrasiTG $>400 \mathrm{mg} / \mathrm{dL}$ atau dalam keadaan tidak puasa) maka dapat digunakan metoda direk (langsung) atau penghitungan kolesterol non-HDL atau apoB. Pemeriksaan kolesterol LDL dengan metoda direk mempunyai keunggulan berupa spesifisitas tinggi dan tidak dipengaruhi oleh variasi TG sehingga dapat direkomendasikan untuk digunakan apabila tersedia. Kolesterol non-HDL dihitung berdasarkan pengurangan kolesterol HDL terhadap kolesterol total.

Penapisan faktor risiko termasuk profil lipidseperti diatas dianjurkan bagi pasien dengan:

- Riwayat PJK prematur dalam keluarga

- Diabetes Mellitus

- Aterosklerosis di pembuluh darah manapun

- Keadaan klinis yang berhubungan dengan penyakit kardiovaskular prematur seperti hipertensi, obesitas (lingkar pinggang $\geq 90 \mathrm{~cm}$ bagi pria dan $\geq 80 \mathrm{~cm}$ bagi wanita), penyakit inflamasi kronik autoimun (SLE, arthritis rematoid, psoriasis), PGK dengan GFR $<60 \mathrm{~mL} / \mathrm{menit} / 1.73 \mathrm{~m}^{2} \mathrm{dan}$ manifestasi klinis dislipidemia genetik (xanthelesma, xanthoma, arkus kornealis prematur).

- Jika tidak terdapat keadaan diatas, maka pemeriksaan dipertimbangkan bagi semua pria $\geq 40$ tahun dan wanita $\geq 50$ tahun atau pascamenopause terutama jika ditemukan adanya faktor risiko lainnya.

\section{Risiko Kardiovaskular Total}

\section{I. Estimasi risiko kardiovaskular total}

Penyakit kardiovaskular merupakan produk dari sejumlah faktor risiko sehingga pencegahannya perlu mempertimbangkan risiko kardiovaskular total.Tujuan estimasi risiko kardiovaskular total adalah menentukan tingkat risiko pasien yang mempunyai dislipidemia. Dengan mengetahui tingkat risiko, diharapkan dapat dilakukan pencegahan terhadap perburukan risiko di masa datang, meningkatkan kesadaran bahaya risiko kardiovaskular, dan melakukan usaha promosi pencegahan primer. Estimasi risiko kardiovaskular total bagi pasien tanpa keluhan atau gejala PJK klinis maupun keadaan yang setara dengan PJK dapat dilakukan dengan menggunakan berbagai risk chart seperti Framingham atau SCORE. ${ }^{33,34}$ Pedoman Tatalaksana Dislipidemia PERKI menganjurkan penggunaan SCORE risk chart. Terdapat 2 pilihan SCORE risk chart yaitu chart untuk negara dengan risiko tinggi dan risiko rendah. Pedoman Tatalaksana Dislipidemia PERKI menganjurkan pemakaian chart untuk negara dengan risiko tinggi (Gambar 1).

Cara penggunaan SCORE risk chart adalah sebagai berikut: 


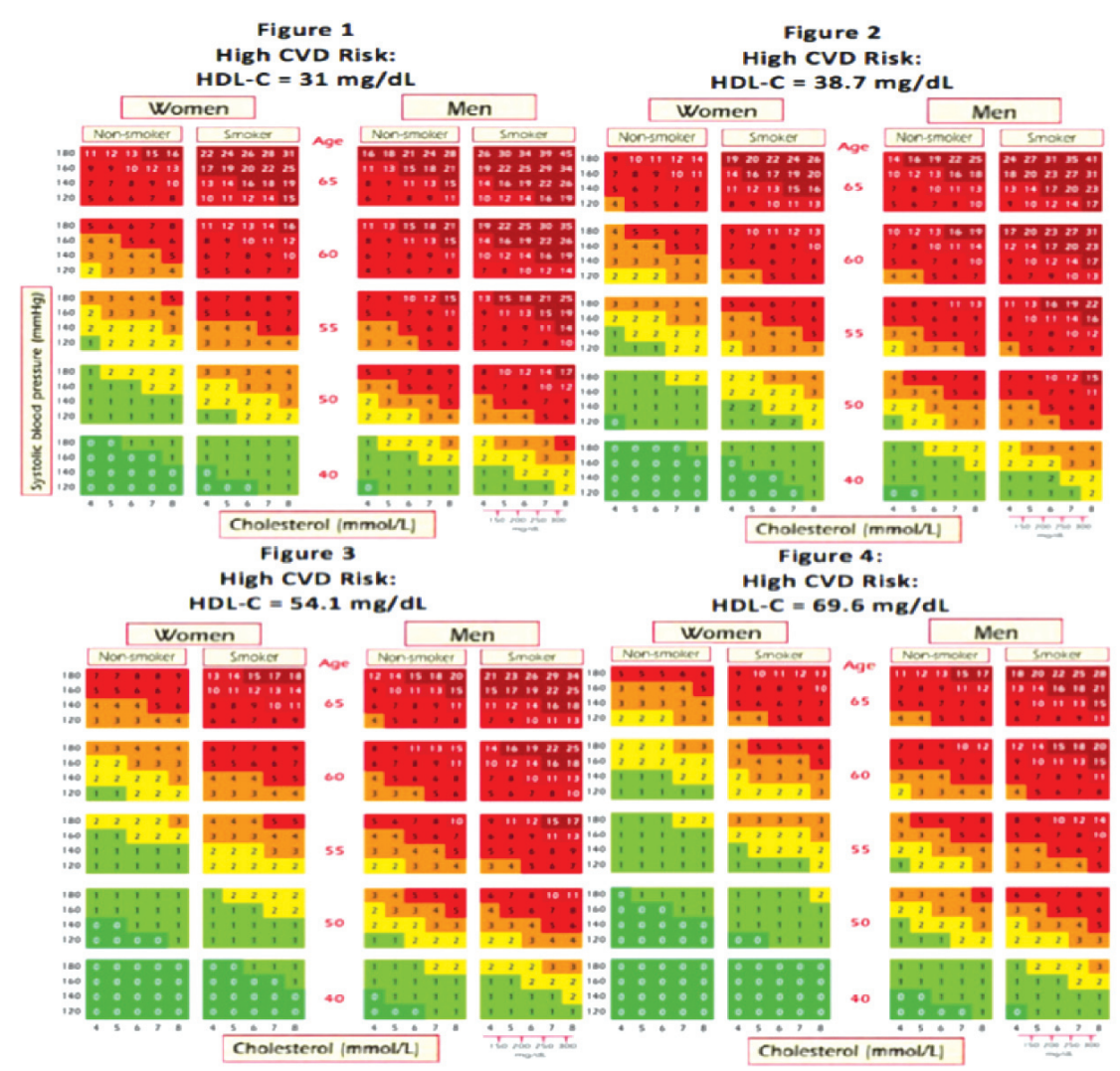

Gambar 1. SCORE chart untuk berbagai nilai kolesterol HDL untuk negara dengan risiko tinggi.35

1. Pilih SCORE riskchart dengan kolesterol HDL yang terdekat dengan kolesterol HDL pasien. Contoh: pilih SCORE risk chart dengan HDL $54,1 \mathrm{mg} / \mathrm{dL}$ bagi pasien dengan kolesterol HDL $50 \mathrm{mg} / \mathrm{dL}$.

2. Dari SCORE risk chart yang terpilih berdasarkan poin 1 selanjutnya pilih SCORE risk chart yang sesuai dengan jenis kelamin dan status merokok pasien.

3. Masukkan konsentrasi kolesterol total ( $\mathrm{mg} / \mathrm{dL}$ atau $\mathrm{mmol} / \mathrm{L}$ ), umur, dan tekanan darah pasien.

4. Angka dalam kotak menunjukkan angka SCORE.

Selain itu, estimasi risiko kardiovaskular total dengan SCORE risk chart juga dapat dihitung secara online di http://www.heartscore.org/.

Perlu diingat bahwa estimasi risiko kardiovaskular total dengan SCORErisk chart tidak berlaku bagi pasien dengan dislipidemia familial atau yang mempunyai konsentrasi kolesterol total diatas $310 \mathrm{mg} /$ dL. Pasien-pasien tersebut selalu termasuk kelompok tingkat risiko tinggi sehingga memerlukan perhatian khusus.

Pasien yang pernah mengalami kejadian klinis seperti sindrom koroner akut, stroke, atau PGK, maupun yang mempunyai faktor risiko tertentu seperti DM, mempunyai risiko kardiovaskular total yang tinggi atau sangat tinggi sehingga memerlukan penanganan yang lebih intensif. Estimasi risiko bagi kelompok pasien ini tidak memakai SCORE risk chart.

\section{2. Tingkat risiko: 35,36}

- Yang termasuk tingkat risiko sangat tinggi adalah pasien dengan

o Penyakit jantung koroner, yaitu:

- terdokumentasi dengan cara invasif maupun non-invasif (angiografi koroner, exercise ECG test,sidik perfusi miokard, ekokardiografi stres)

- angina stabil

- sindrom koroner akut

- pasca infark miokard 
- pernah menjalani revaskularisasi koroner (intervensi koroner perkutan atau bedah pintas koroner)

o Setara PJK, yaitu:

- Diabetes Mellitus tipe 2

- Diabetes Mellitus tipe 1 dengan mikroalbuminuria

- gagal ginjal kronik dengan GFR <60 mL/ menit $/ 1.73 \mathrm{~m}^{2}$

- penyakit arteri karotis (TIA, stroke, atau penyumbatan arteri karotis $>50 \%$ dengan ultrasonografi)

- penyakit arteri perifer

o Nilai SCORE $\geq 10 \%$

- Yang termasuk tingkat risiko tinggi adalah pasien dengan

o faktor risiko tunggal yang berat seperti dislipidemia familial atau hipertensi berat

o sindrom metabolik

o angka SCORE 5 sampai $<10 \%$

- Yang termasuk tingkat risiko menengah adalah pasien dengan angka SCORE $\geq 1 \%$ dan $5 \%$. Kebanyakan pasien usia pertengahan mempunyai risiko menengah. Risiko ini perlu dimodulasi lebih lanjut dengan mempertimbangkan faktor risiko lain seperti riwayat PJK prematur dalam keluarga, obesitas abdominal, kolesterol HDL yang rendah, dan konsentrasiTG tinggi.

- Yang termasuk tingkat risiko rendah adalah pasien dengan angka SCORE $<1 \%$.

\section{Target Terapi}

Dasar dari target terapi adalah penelitian klinis. Sebagian besar penelitian klinis menggunakan kolesterol LDL sebagai target terapi sehingga kolesterol LDL menjadi target primer terapi dislipidemia. Besaran target konsentrasi kolesterol LDL pada berbagai tingkat risiko kardiovaskular diperkirakan dengan cara ekstrapolasi dari data penelitian klinis tersebut.

Besarnya reduksi risiko kardiovaskular sesuai dengan besarnya penurunan kolesterol LDL. Setiap penurunan $1 \mathrm{mmol} / \mathrm{L}(40 \mathrm{mg} / \mathrm{dL})$ kolesterol LDL berhubungan dengan reduksi $22 \%$ mortalitas dan morbiditas kardiovaskular. Berdasarkan ekstrapolasi dari berbagai studi klinis, keuntungan terbesar dalam reduksi risiko kardiovaskular berhubungan dengan penurunan kolesterol LDL ke konsentrasi kurang dari
$70 \mathrm{mg} / \mathrm{dL}$ atau tercapainya penurunan relatif minimal $50 \%$ dari konsentrasiawal. ${ }^{9}$

Target terapi kolesterol LDL bagi pasien dengan risiko kardiovaskular sangat tinggi adalah $<70 \mathrm{mg} / \mathrm{dL}$ atau penurunan $\geq 50 \%$ dari konsentrasi awal. Bagi pasien dengan risiko tinggi, target terapinya adalah $<100 \mathrm{mg} / \mathrm{dL}$ atau penurunan $\geq 30 \%$ dari konsentrasi awal. ${ }^{35,36}$ Perlu diingat bahwa target penurunan dari konsentrasi awal sebesar $\geq 50 \%$ bagi pasien dengan risiko kardiovaskular sangat tinggi hendaknya hanya diberlakukan jika konsentrasikolesterol LDL awal sangat tinggi sehingga target $<70 \mathrm{mg} / \mathrm{dL}$ tidak dapat dicapai dengan terapi farmakologis. Hal yang sama juga berlaku bagi pasien dengan tingkat risiko kardiovaskular tinggi. Target terapi kolesterol LDL bagi pasien berisiko menengah adalah $<115 \mathrm{mg} /$ dL. ${ }^{35}$ Bagi yang berisiko rendah, target terapi harus mempertimbangkan keuntungan dan kerugian terapi obat penurun lipid. Besaran target konsentrasi kolesterol LDL pada pasien dengan risiko kardiovaskular rendah lebih banyak ditentukan oleh studi observasional yang meneliti hubungan antara konsentrasi kolesterol LDL dengan aterogenesis dan kejadian PJK. Pasien yang mempunyai konsentrasi kolesterol LDL di bawah $100 \mathrm{mg} / \mathrm{dL}$ selama hidupnya mempunyai risiko rendah terkena PJK dibanding pasien lain dalam populasi. Oleh karena itu, kolesterol LDL $<100 \mathrm{mg} /$ $\mathrm{dL}$ dianggap sebagai konsentrasi optimal. Konsentrasi antara tingkat optimal dan perbatasan tinggi (100$129 \mathrm{mg} / \mathrm{dL}$ ) disebut di atas optimal. Pada konsentrasi kolesterol LDL 130-159 mg/dL (tingkat perbatasan tinggi), aterogenesis terjadi dengan cepat. Aterogenesis terjadi sangat cepat jika konsentrasi kolesterol LDL tinggi (160-189 $\mathrm{mg} / \mathrm{dL})$ atau sangat tinggi $(\geq 190$ $\mathrm{mg} / \mathrm{dL}$ ). Hubungan antara konsentrasi kolesterol LDL dan kejadian PJK dipastikan oleh beberapa studi. ${ }^{37,38}$ Idealnya, target konsentrasi kolesterol LDL adalah $<100 \mathrm{mg} / \mathrm{dL}$ tetapi jika diberlakukan pada setiap orang dengan risiko rendah akan menjadi tidak realistis. Pedoman tatalaksana yang ada pada umumnya merekomendasikan terapi obat penurun lipid pada pasien berisiko rendah jika konsentrasi kolesterol LDL $>190 \mathrm{mg} / \mathrm{dL}$ setelah intervensi gaya hidup gagal menurunkan ke konsentrasi $<190 \mathrm{mg} / \mathrm{dL}$. ${ }^{35,36}$

Mengingat kolesterol non-HDL belum dimasukkan kedalam target terapi pada penelitian klinis acak, sementara parameter lipid ini menunjukkan keberadaan lipid aterogenik, maka kolesterol nonHDL belum menjadi target primer melainkan menjadi target sekunder terapi penurun lipid. Yang disebut 
target sekunder adalah targetterapi yang hendaknya dicapai setelah target primer tercapai pada pasien dengan hipertrigliseridemia yang menyertai DM, sindrom metabolik, dan PGK.

Target kolesterol non-HDL adalah $30 \mathrm{mg} / \mathrm{dL}$ diatas target kolesterol LDL. Mengingat target kolesterol LDL bagi pasien dengan risiko sangat tinggi adalah $<70$ $\mathrm{mg} / \mathrm{dL}$ maka target untuk kolesterol non-HDL adalah $<100 \mathrm{mg} / \mathrm{dL}$. Sementara itu, target kolesterol non-HDL untuk pasien dengan risiko tinggi adalah $<130 \mathrm{mg} / \mathrm{dL}$. Target ini sesuai dengan konsentrasikolesterol VLDL pada pasien yang mempunyai konsentrasiTG $>150$ $\mathrm{mg} / \mathrm{dL}$. Konsentrasi kolesterol VLDL "normal” yang besarnya $<30 \mathrm{mg} / \mathrm{dL}$ adalah konsentrasi kolesterol VLDL ketika konsentrasiTG" "normal" yaitu <150 mg/ dL. ${ }^{39}$ Sebaliknya, ketika konsentrasi TG $\geq 150 \mathrm{mg} / \mathrm{dL}$, konsentrasi kolesterol non-HDL biasanya $\geq 30 \mathrm{mg} / \mathrm{dL}$. Mengingat kolesterol non-HDL adalah perjumlahan dari kolesterol VLDL dan LDL maka target yang masuk akal bagi kolesterol non-HDL adalah $30 \mathrm{mg} /$ dL lebih tinggi dari konsentrasi kolesterol LDL.

Konsentrasi ApoB berkorelasi dengan konsentrasi kolesterol non-HDL tetapi pemeriksaannya lebih mahal. Jika ApoB diperiksa, maka target terapinya adalah $<80 \mathrm{mg} / \mathrm{dL}$ untuk pasien berisiko sangat tinggi dan $<100 \mathrm{mg} / \mathrm{dL}$ bagi pasien dengan risiko tinggi. ${ }^{35}$

Kolesterol HDL saat ini dipergunakan untuk estimasi risiko kardiovaskular dan tidak menjadi target terapi ${ }^{35}$ karena studi klinisnya tidak meyakinkan ${ }^{11,12}$ bahkan pada pasien risiko tinggi dengan konsentrasi kolesterol LDL yang telah mencapai target terapi. ${ }^{13}$

Lipoprotein(a) merupakan penanda risiko tambahan yang tidak dianjurkan diperiksa secara rutin. ${ }^{25}$ Lipoprotein(a) dapat direkomendasikan diperiksa pada pasien dengan tingkat risiko sedang atau tinggi yang mempunyai penyakit kardiovaskular prematur, dislipidemia familial, riwayat penyakit kardiovaskular prematur dalam keluarga, dan penyakit kardiovaskular berulang walau telah mendapat terapi statin. Khusus untuk keadaan di atas, terapi dianjurkan jika ditemukan konsentrasi Lp(a) $>50 \mathrm{mg} /$ $\mathrm{dL}$ pada pasien yang telah mencapai target konsentrasi kolesterol LDL. Target terapi Lp(a) adalah konsentrasi $\leq 50 \mathrm{mg} / \mathrm{dL} .{ }^{40}$

Pemeriksaan apoB/apoA1 dalam penapisan risiko tidak dianjurkan. ${ }^{35}$ Small, dense LDL saat ini tidak direkomendasikan untuk diperiksa ${ }^{41}$ mengingat belum ada penelitian klinis yang mengevaluasi hubungan antara penurunan jumlah partikel small, dense LDL dengan reduksi risiko kardiovaskular melebihi yang dicapai oleh penurunan konsentrasi kolesterol LDL.

\section{Strategi Intervensi}

\section{I. Target parameter lipid}

- Primer: kolesterol LDL

- Sekunder: kolesterol non-HDL

\section{2. Prinsip strategi intervensi}

- Selalu mempertimbangkan tingkat risiko kardiovaskular total

- Semua pasien, kecuali yang tingkat risikonya rendah dan mempunyai konsentrasi kolesterol LDL praterapi $<100 \mathrm{mg} / \mathrm{dL}$, perlu mendapat intervensi perubahan gaya hidup.

- Intervensi farmakologis dengan obat penurun lipid terhadap target primer dilakukan pada pasien dengan konsentrasi awal kolesterol LDL di atas target terapi.

- Intervensi dengan obat penurun lipid terhadap target sekunder (kolesterol non-HDL) hanya dilakukan pada pasien dengan tingkat risiko tinggi dan sangat tinggi yang target kolesterol LDL-nya telah tercapai sementara konsentrasiTG masih di atas $200 \mathrm{mg} / \mathrm{dL}$.

\section{3. Intervensi kolesterol LDL}

- Pertimbangkan adanya penyebab sekunder peningkatan kolesterol LDL sebagai berikut: ${ }^{35}$
o Hipotiroidisme
o Sindrom nefrotik
o Kehamilan
o Sindrom Cushing
o Anoreksia nervosa
o Penggunaan agen-agen imunosupresan
o Kortikosteroid

- Tabel 1 menunjukkan bahwa: ${ }^{35}$

o Intervensi gaya hidup tanpa intervensi farmakologis ditujukan bagi pasien dengan:

- Tingkat risiko rendah yang mempunyai konsentrasi kolesterol awal $100-<190 \mathrm{mg} / \mathrm{dL}$

- Tingkat risiko menengah yang mempunyai konsentrasi kolesterol LDL awal $<100 \mathrm{mg} /$ $\mathrm{dL}$

- Tingkat risiko tinggi yang mempunyai 
Tabel 1. Strategi intervensi sebagai fungsi dari risiko kardiovaskular total dan konsentrasi kolesterol LDL ${ }^{35}$

\begin{tabular}{|c|c|c|c|c|c|}
\hline \multirow{3}{*}{$\begin{array}{l}\text { Total Risiko } \\
\text { Kardiovaskular } \\
\text { (SCORE) }\end{array}$} & \multicolumn{5}{|c|}{ Nilai Kolesterol LDL } \\
\hline & $<70 \mathrm{mg} / \mathrm{dL}$ & $70-<100 \mathrm{mg} / \mathrm{dL}$ & $100-<155 \mathrm{mg} / \mathrm{dL}$ & $155-<190 \mathrm{mg} / \mathrm{dL}$ & $>190 \mathrm{mg} / \mathrm{dL}$ \\
\hline & $<1,8 \mathrm{mmol} / \mathrm{L}$ & $1,8-2,5 \mathrm{mmol} / \mathrm{L}$ & $2,5-4 \mathrm{mmol} / \mathrm{L}$ & $4-4,9 \mathrm{mmol} / \mathrm{L}$ & $>4,9 \mathrm{mmol} / \mathrm{L}$ \\
\hline$<1$ & $\begin{array}{l}\text { Tidak ada in- } \\
\text { tervensi lipid }\end{array}$ & $\begin{array}{l}\text { Tidak ada intervensi } \\
\text { lipid }\end{array}$ & Intervensi gaya hidup & Intervensi gaya hidup & $\begin{array}{l}\text { Intervensi gaya } \\
\text { hidup, pertim- } \\
\text { bangkan obat bila } \\
\text { tidak terkontrol }\end{array}$ \\
\hline$\geq 1-<5$ & $\begin{array}{l}\text { Intervensi gaya } \\
\text { hidup }\end{array}$ & $\begin{array}{l}\text { Intervensi gaya } \\
\text { hidup }\end{array}$ & $\begin{array}{l}\text { Intervensi gaya hidup, } \\
\text { pertimbangkan obat } \\
\text { bila tidak terkontrol }\end{array}$ & $\begin{array}{l}\text { Intervensi gaya } \\
\text { hidup, pertimbang- } \\
\text { kan obat bila tidak } \\
\text { terkontrol }\end{array}$ & $\begin{array}{l}\text { Intervensi gaya } \\
\text { hidup, pertim- } \\
\text { bangkan obat bila } \\
\text { tidak terkontrol }\end{array}$ \\
\hline $\begin{array}{l}>5-<10 \text { (risiko } \\
\text { tinggi) }\end{array}$ & $\begin{array}{l}\text { Intervensi gaya } \\
\text { hidup, pertim- } \\
\text { bangkan obat* }\end{array}$ & $\begin{array}{l}\text { Intervensi gaya } \\
\text { hidup, pertimbang- } \\
\text { kan obat* }\end{array}$ & $\begin{array}{l}\text { Intervensi gaya hidup } \\
\text { dan pemberian obat } \\
\text { segera }\end{array}$ & $\begin{array}{l}\text { Intervensi gaya hidup } \\
\text { dan pemberian obat } \\
\text { segera }\end{array}$ & $\begin{array}{l}\text { Intervensi gaya } \\
\text { hidup dan pembe- } \\
\text { rian obat segera }\end{array}$ \\
\hline $\begin{array}{l}\geq 10 \text { (risiko } \\
\text { sangat tinggi) }\end{array}$ & $\begin{array}{l}\text { Intervensi gaya } \\
\text { hidup, pertim- } \\
\text { bangkan obat* }\end{array}$ & $\begin{array}{l}\text { Intervensi gaya } \\
\text { hidup dan pembe- } \\
\text { rian obat segera }\end{array}$ & $\begin{array}{l}\text { Intervensi gaya hidup } \\
\text { dan pemberian obat } \\
\text { segera }\end{array}$ & $\begin{array}{l}\text { Intervensi gaya hidup } \\
\text { dan pemberian obat } \\
\text { segera }\end{array}$ & $\begin{array}{l}\text { Intervensi gaya } \\
\text { hidup dan pembe- } \\
\text { rian obat segera }\end{array}$ \\
\hline
\end{tabular}

* Pada pasien dengan infark miokard, terapi statin harus dipertimbangkan tanpa melihat nilai kolesterol LDL.

konsentrasi kolesterol LDL awal $<100$ $\mathrm{mg} / \mathrm{dLk}$ ecuali pada pasien dengan infark miokard

- Tingkat risiko sangat tinggi yang mempunyai konsentrasi kolesterol LDL awal $<70 \mathrm{mg} / \mathrm{dL}$ kecuali pada pasien dengan infark miokard

o Keadaan di bawah ini memerlukan intervensi gaya hidup yang dilanjutkan dengan intervensi farmakologis jika intervensi gaya hidup gagal menurunkan kolesterol LDL mencapai target terapi:

- Tingkat risiko rendah yang mempunyai konsentrasi kolesterol LDL >190 mg/dL setelah terapi gaya hidup

- Tingkat risiko menengah yang mempunyai konsentrasi kolesterol LDL $\geq 100 \mathrm{mg} / \mathrm{dL}$ setelah intervensi gaya hidup

Efek intervensi gaya hidup terhadap konsentrasi kolesterol LDL dievaluasi dalam waktu 3 bulan dengan pengukuran konsentrasi kolesterol LDL setiap 6 minggu. Evaluasi ulang konsentrasi kolesterol LDL dilakukan setiap 4-6 bulan pada tahun pertama dan setiap 6-12 bulan sesudahnya ${ }^{36}$

o Intervensi gaya hidup dan farmakologis pada saat bersamaan ditujukan bagi pasien dengan:
- Infark miokard akut tanpa memandang konsentrasi LDL awal

- Tingkat risiko tinggi dengan konsentrasi kolesterol LDL awal $\geq 100 \mathrm{mg} / \mathrm{dL}$

- Tingkat risiko sangat tinggi dengan konsentrasi kolesterol LDL awal $\geq 70$ $\mathrm{mg} / \mathrm{dL}$ kecuali pada pasien dengan infark miokard (terapi statin diberikan tanpa memandang konsentrasi kolesterol LDL)

- Diabetes Melltius tipe 2 yang berumur di bawah 40 tahun tanpa faktor risiko lain, terapi farmakologis dimulai jika konsentrasi kolesterol LDL $\geq 100 \mathrm{mg} /$ $\mathrm{dL}$

- Statin adalah obat pilihan penurun konsentrasi kolesterol LDL dan digunakan sampai dosis terbesar yang dapat ditoleransi untuk mencapai target konsentrasi kolesterol LDL. Ketika konsentrasi awal sangat tinggi sehingga konsentrasi kolesterol LDL tidak mencapai target terapi absolut dengan statin dosis tinggi, maka dianjurkan untuk mencapai target terapi relatif, yaitu penurunan minimal $50 \%$ pada pasien dengan tingkat risiko sangat tinggi atau minimal $30 \%$ bagi pasien dengan tingkat risiko tinggi. Dalam keadaan target terapi relatif tidak tercapai, dapat dipertimbangkan kombinasi antara statin dengan ezetimibe atau bile acid sequestrantatau asam nikotinat. Dalam keadaan tidak toleran terhadap statin, dapat 
digunakan terapi tunggal bile acid sequestrant atau asam nikotinat. ${ }^{35}$

- Terdapat perbedaan kemampuan berbagai jenis statin dalam menurunkan kolesterol LDL pada dosis maksimalnya. ${ }^{42}$ Pemilihan jenis statin mempertimbangkan besarnya persentase penurunan konsentrasi kolesterol praterapi menuju target.

\section{4. Intervensi kolesterol non-HDL}

- Intervensi kolesterol non-HDL yang meningkat ( $\geq 30 \mathrm{mg} / \mathrm{dL}$ di atas target kolesterol LDL) hanya dilakukan jika konsentrasi LDL telah mencapai konsentrasi target terapi (absolut atau relatif) sehingga intervensi konsentrasi kolesterol nonHDL pada keadaan ini pada dasarnya adalah mengontrol konsentrasi TG. Pada keadaan ini, intervensi TG dilakukan pada pasien dengan tingkat risiko tinggi atau sangat tinggi yang mempunyai konsentrasi TG $\geq 200 \mathrm{mg} / \mathrm{dL}$. ${ }^{43-45}$

- Sebelum melakukan terapi penurun TG, pertimbangkan adanya penyebab sekunder peningkatan konsentrasi TG, antara lain: ${ }^{35}$

o Predisposisi genetik

o Obesitas

o DM tipe 2

o Konsumsi alkohol

o Diet tinggi karbohidrat sederhana

o Penyakit ginjal

o Hipotiroidisme

o Kehamilan (konsentrasi TG berlipatganda secara fisiologis pada trimester ketiga)

o Kelainan autoimun, seperti paraproteinemia atau SLE

o Berbagai pengobatan, termasuk di antaranya

- Kortikosteroid

- Estrogen, terutama yang dikonsumsi secara oral

- Tamoxifen

- Anti-hipertensi seperti ß-bloker (termasuk carvedilol), tiazid

- Isotretinoin

- Resin yang mengikat asam empedu

- Siklosporin

- Antiretroviral (inhibitor protease)

- Psikotropika seperti fenotiazin, antipsikotika generasi kedua

o Mengingat pankreatitis dapat terjadi pada konsentrasi TG $400 \mathrm{mg} / \mathrm{dL}$ maka pasien dengan konsentrasi TG $\geq 400 \mathrm{mg} / \mathrm{dL}$ harus segera diterapi tanpa memandang tingkat risiko kardiovaskular dan konsentrasi kolesterol LDL.

o Pilihan obat sesuai dengan Tabel 2.

Tabel 2. Pilihan pengobatan hipertrigliseridemia ${ }^{35}$

\begin{tabular}{|l|}
\hline Direkomendasikan: \\
Fibrat \\
\hline Perlu dipertimbangkan: \\
Asam nikotinat \\
Asam nikotinat + laropiprant \\
PUFA omega-3 \\
Statin + asam nikotinat \\
Statin + fibrat \\
\hline Dapat dipertimbangkan: \\
Kombinasi dengan PUFA omega-3 \\
\hline
\end{tabular}

- Statin terbukti dapat menurunkan mortalitas dan morbiditas kardiovaskular, maka obat ini adalah pilihan pertama bagi pasien dengan tingkat risiko tinggi dan sangat tinggi yang mempunyai konsentrasi TG moderat. Statin potensi tinggi seperti atorvastatin dan rosuvastatin, terutama pada dosis tinggi, terbukti mampu menurunkan konsentrasi TG. Dalam keadaan statin tidak dapat menurunkan konsentrasi TG sehingga konsentrasi kolesterol non-HDL masih $\geq 30 \mathrm{mg} / \mathrm{dL}$ diatas target kolesterol LDL, fibrat dapat ditambahkan pada statin. Dalam hal ini, fenofibrat lebih terpilih daripada gemfibrozil mengingat risiko miopati 15 kali lebih tinggi jika digunakan gemfibrozil daripada fenofibrat. ${ }^{46}$

\section{5. Intervensi kolesterol HDL}

Studi post hoc menunjukkan bahwa konsentrasi kolesterol HDL dapat memprediksi kejadian kardiovaskular pada pasien risiko sangat tinggi dengan konsentrasi kolesterol LDL di bawah $70 \mathrm{mg} / \mathrm{dL} .^{10}$ Walau demikian, kolesterol HDL yang rendah bukan target intervensi farmakologis walau kolesterol LDL telah mencapai target terapi. ${ }^{13}$

\section{Intervensi Gaya Hidup Untuk Memperbaiki Profil Lipid}

Bukti penurunan morbiditas dan mortalitas kardiovaskular yang berhubungan dengan intervensi gaya 
hidup tidak sekuat bukti yang berhubungan dengan intervensi farmakologis. Pentingnya konseling intervensi gaya hidup terutama berhubungan dengan perubahan positif terhadap perilaku untuk mengontrol profil lipid. ${ }^{47}$ Tujuan intervensi gaya hidup adalah untuk mengurangi kolesterol LDL, mengurangi konsentrasiTG, dan meningkatkan kolesterol HDL. Intervensi gaya hidup dilakukan pada semua orang, dengan atau tanpa tambahan obat penurun lipid, kecuali pada pasienrisiko rendah dengan kolesterol LDL awal $<100 \mathrm{mg} / \mathrm{dL}$. Pasienrisiko rendah ini hanya perlu diyakinkan agar tetap dalam keadaan risiko rendah. Usaha yang dapat dilakukan antara lain mengurangi asupan asam lemak jenuh, meningkatkan asupan serat, mengurangi asupan karbohidrat dan alkohol, meningkatkan aktivitas fisik sehari-hari, mengurangi berat badan berlebih dan menghentikan kebiasaan merokok (Tabel 3).
konsentrasiTG. ${ }^{48}$ Data dari penelitian klinis acak, kasus keloladan kohor menunjukkan bahwa konsumsi PUFA omega-6 setidaknya 5\% hingga 10\% dari total energi mereduksi risiko PJK. ${ }^{49}$ Konsumsi PUFA omega-3, PUFA omega-6 dan MUFA berhubungan dengan peningkatan konsentrasi kolesterol HDL sampai 5\% dan penurunan TG sebesar 10-15\%.48,50,51

Asam lemak trans diproduksi dari minyak nabati dengan cara hidrogenasi, dan dapat ditemukan secara alami di dalam lemak hewani. Asam lemak trans meningkatkan kolesterol $\mathrm{LDL}^{52,53}$ dan menurunkan kolesterol HDL. ${ }^{54}$ Sumber asam lemak trans di dalam diet biasanya berasal dari produk yang terbuat dari minyak terhidrogenasi parsial seperti biskuit asin (crackers), kue kering manis (cookies), donat, roti dan makanan lain seperti kentang goreng atau ayam yang digoreng memakai minyak nabati yang dihidrogenasi. ${ }^{23}$

Tabel 3. Intervensi gaya hidup yang dapat dilakukan untuk mengurangi kolesterol LDL, kolesterol HDL dan TG. ${ }^{35}$

\begin{tabular}{|l|l|l|}
\hline \multicolumn{3}{|c|}{ Intervensi gaya hidup ditujukan untuk: } \\
\hline Menurunkan Kolesterol LDL & Meningkatkan Kolesterol HDL & Menurunkan TG \\
\hline Kurangi asupan lemak jenuh & Kurangi jumlah asupan karbohidrat \\
\hline Tingkatkan asupan serat & & Kurangi asupan alkohol \\
\hline \multicolumn{3}{|l|}{} \\
\hline Tingkatkan aktivitas fisik sehari-hari & Berhenti merokok & \\
\hline Kurangi berat badan berlebih &
\end{tabular}

\section{I.Diet}

Diet yang dapat dipakai untuk menurunkan kolesterol LDL adalah diet asam lemak tidak jenuh seperti MUFA dan PUFA karena faktor diet yang paling berpengaruh terhadap peningkatan konsentrasi kolesterol LDL adalah asam lemak jenuh. Penurunan kolesterol LDL yang diakibatkan oleh dietPUFAlebih besar dibandingkan dengan diet MUFA atau diet rendah karbohidrat. PUFA omega-3 tidak mempunyai efek hipokolesterolemik langsung, tetapi kebiasaan mengonsumsi ikan (mengandung banyak PUFA omega-3) berhubungan dengan reduksi risiko kardiovaskular independen terhadap efek pada lipid plasma. Konsumsi PUFA omega-3 pada dosis farmakologis ( $>2$ gram/hari) mempunyai efek netral terhadap konsentrasi kolesterol LDL dan mengurangi
Diet karbohidrat bersifat netral terhadap kolesterol LDL, sehingga makanan kaya karbohidrat merupakan salah satu pilihan untuk menggantikan diet lemak jenuh. ${ }^{55}$ Di lain pihak, diet kaya karbohidrat ( $>60 \%$ kalori total) berhubungan dengan penurunan konsentrasi kolesterol HDL dan peningkatan konsentrasi TG. Oleh karena itu, asupan karbohidrat dianjurkan kurang dari 60\% kalori total. Asupan lebih rendah dianjurkan bagi pasien dengan peningkatan konsentrasi TG dan konsentrasi kolesterol HDL rendah seperti yang ditemukan pada pasien sindrom metabolik. ${ }^{23}$ Diet karbohidrat yang kaya serat dianggap diet optimal pengganti lemak jenuh yang tujuannya meningkatkan efek diet pada konsentrasi kolesterol LDL dan mengurangi efek yang tidak dikehendaki dari diet kaya karbohidrat pada lipoprotein lain. ${ }^{56} \mathrm{Diet}$ makanan tinggi serat seperti kacang-kacangan, buah, 
sayur dan sereal memiliki efek hipokolesterolemik langsung.

\section{2. Aktivitas fisik}

Tujuan melakukan aktivitas fisik secara teratur adalah mencapai berat badan ideal, mengurangi risiko terjadinya sindrom metabolik, dan mengontrol faktor risiko PJK. Pengaruh aktivitas fisik terhadap parameter lipid terutama berupa penurunan TG dan peningkatan kolesterol HDL. Olahraga aerobik dapat menurunkan konsentrasi TG sampai 20\% dan meningkatkan konsentrasi kolesterol HDL sampai $10 \% .{ }^{57,58}$ Sementara itu, olahraga resisten hanya menurunkan TG sebesar 5\% tanpa pengaruh terhadap konsentrasi HDL. ${ }^{59,60}$ Efek penurunan TG dari aktivitas fisik sangat tergantung pada konsentrasi TG awal, tingkat aktivitas fisik, dan penurunan berat badan. ${ }^{61-63}$ Tanpa disertai diet dan penurunan berat badan, aktivitas fisik tidak berpengaruh terhadap kolesterol total dan LDL. ${ }^{64}$

Aktivitas fisik yang dianjurkan adalah aktivitas yang terukur seperti jalan cepat 30 menit perhari selama 5 hari per minggu atau aktivitas lain setara dengan 4-7 kkal/menit atau 3-6 METs. Beberapa jenis latihan fisik lainnya antara lain: ${ }^{23}$

- Berjalan cepat (4,8-6,4 km per jam) selama 30-40 menit

- Berenang - selama 20 menit

- Bersepeda untuk kesenangan atau transportasi, jarak 8 km dalam 30 menit

- Bermain voli selama 45 menit

- Menyapu halaman selama 30 menit

- Menggunakan mesin pemotong rumput yang didorong selama 30 menit

- Membersihkan rumah (secara besar-besaran)

- Bermain basket selama 15 hingga 20 menit

- Bermain golf tanpa $c a d d y$ (mengangkat peralatan golf sendiri)

- Berdansa selama 30 menit

\section{3. Penurunan berat badan}

Indeks Masa Tubuh dan lingkar pinggang dipakai sebagai ukuran untuk menilai obesitas umum dan obesitas abdominal. Baik obesitas umum maupun obesitas abdominal berhubungan dengan risiko kematian. ${ }^{65}$ Konsep obesitas terutama dihubungkan dengan konsep sindrom metabolik. Untuk semua pasien dengan kelebihan berat badan hendaknya diusahakan untuk mengurangi $10 \%$ berat badan. ${ }^{23}$ Walaupun ukuran antropometri lain seperti lingkar pinggang atau rasio pinggul terhadap pinggang dapat menambah informasi, IMT sendiri adalah prediktor kuat untuk mortalitas secara keseluruhan.Lingkar pinggang normal untuk Asia adalah $<90 \mathrm{~cm}$ untuk pria dan $<80 \mathrm{~cm}$ untuk wanita. ${ }^{35,66}$ Bertambahnya mortalitas secara progresif akibat peningkatan IMT terutama berhubungan dengan mortalitas penyakit vaskular. Hubungan antara IMT dengan kematian di Asia menunjukkan perbedaan antar etnis. Indeks Masa Tubuh yang tinggi berhubungan dengan peningkatan mortalitas pada etnis Asia Timur (Cina, Jepang dan Korea), tetapi tidak pada etnis India dan Bangladesh. Kesepakatan klasifikasi IMT untuk populasi Asia dapat dilihat pada Tabel 4.

Tabel 4. Klasifikasi IMT untuk populasi Asia dewasa. ${ }^{67}$

\begin{tabular}{|l|l|}
\hline Klasifikasi & IMT $\left(\mathrm{kg} / \mathrm{m}^{2}\right)$ \\
\hline Berat Badan Kurang & $<18,5$ \\
\hline Normal & $18,5-22,9$ \\
\hline Berat Badan Lebih: & $\geq 23$ \\
Berisiko & $23-24,9$ \\
Obesitas I & $25-29,9$ \\
Obesitas II & $\geq 30$ \\
\hline
\end{tabular}

Walau pengaruh penurunan berat badan terhadap kolesterol total dan LDL hanya sedikit, untuk semua pasien dengan kelebihan berat badan direkomendasikan untuk mengurangi $10 \%$ berat badan. ${ }^{23}$ Setiap penurunan $10 \mathrm{~kg}$ berat badan berhubungan dengan penurunan kolesterol LDL sebesar $8 \mathrm{mg} / \mathrm{dL}$. Konsentrasi kolesterol HDL justru berkurang saat sedang aktif menurunkan berat badan dan akan meningkat ketika berat badan sudah stabil. Setiap penurunan $1 \mathrm{~kg}$ berat badan berhubungan dengan peningkatan kolesterol HDL sebesar $4 \mathrm{mg} / \mathrm{dL}$ dan penurunan konsentrasi TG sebesar $1,3 \mathrm{mg} / \mathrm{dL} .{ }^{68}$ Sebuah studi dengan masa pemantauan maksimum 13,5 tahun menunjukkan bahwa intervensi gaya hidup yang intensif pada penderita DM tipe 2 dengan kelebihan berat badan (overweight) atau obesitas tidak menurunkan kolesterol LDL tetapi menurunkan HbA1C dan semua risiko kardiovaskular. Studi ini menunjukkan bahwa intervensi berupa penurunan berat badan minimal 7\%, meningkatan aktivitas fisik, dan mengurangi asupan kalori pada pasien yang 
mendapat terapi obat proteksi kardiovaskular tidak menurunkan laju kejadian kardiovaskular. ${ }^{69}$

\section{4. Menghentikan kebiasaan merokok}

Menghentikan merokok dapat meningkatkan konsentrasi kolesterol HDL sebesar 5-10\%. ${ }^{70}$ Merokok berhubungan dengan peningkatan konsentrasi TG, ${ }^{71,72}$ tetapi menghentikan merokok diragukan menyebabkan penurunan konsentrasi TG. ${ }^{70}$

\section{5. Diet suplemen}

a) Fitosterol

Fitosterol berkompetisi dengan absorbsi kolesterol di usus sehingga dapat menurunkan konsentrasi kolesterol total. Secara alami, fitosterol banyak didapat dalam minyak nabati dan, dalam jumlah lebih sedikit, dalam buah segar, kacang kenari, dan kacang polong. Fitosterol sering ditemukan sebagai bahan tambahan pada minyak goreng dan mentega. Konsumsi fitosterol sebagai diet suplemen menurunkan kolesterol LDL sampai 15\%. ${ }^{73,74}$ Asupan sebesar 2 gram/hari dianggap sebagai pilihan terapi untuk menurunkan kolesterol LDL. ${ }^{23}$ Asupan lebih dari 3 gram perhari tidak menurunkan konsentrasi kolesterol lebih lanjut. Sampai saat ini belum ada bukti penurunan risiko kardiovaskular akibat konsumsi fitosterol. ${ }^{74}$ Fitosterol tidak atau sedikit berpengaruh terhadap kolesterol HDL dan TG. ${ }^{75}$

b) Protein kedelai

Protein kedelai berhubungan dengan penurunan 3-5\% kolesterol LDL. ${ }^{76}$ Sebagian besar studi menggunakan asupan protein kedelai lebih dari $40 \mathrm{mg} /$ hari. Sebuah studi menunjukkan asupan $25 \mathrm{mg} /$ hari berhubungan dengan penurunan kolesterol LDL sebesar $5 \mathrm{mg} / \mathrm{dL} .{ }^{77}$

c) Makanan kaya serat

Diet serat yang larut dalam air seperti kacang polong, sayuran, buah, dan sereal mempunyai efek hipokolesterolemik. ${ }^{56}$ Diet serat yang larut dalam air sebanyak 5-10 gram/hari dapat menurunkan kolesterol LDL sebesar 5\%. ${ }^{78,79}$ Anjuran diet serat yang larut dalam air untuk menurunkan kolesterol LDL adalah 5-15 gram/hari. ${ }^{80}$

d) PUFA Omega-3

Polyunsaturated fatty acido mega-3 adalah komponen yang ada dalam minyak ikan atau diet mediterania. Asupan PUFA omega-3 yang berasal dari produk laut (seperti minyak ikan) sebesar 4 gram sehari dilaporkan menurunkan konsentrasi TG 25-30\%, menurunkan konsentrasi kolesterol LDL 5-10\%, dan menaikkan konsentrasi kolesterol HDL sebesar 1-3\%. ${ }^{81}$ Produk laut mengandung banyak PUFA omega-3 rantai panjang seperti EPA dan DHA. Polyunsaturated fatty acid omega-3 yang berasal dari tanaman seperti kedelai dan kenari mengandung asam linolenik alfa (PUFA rantai moderat) yang tidak menurunkan konsentrasi TG secara konsisten. ${ }^{82}$ Dosis farmakologis untuk menurunkan konsentrasi TG adalah $>2$ gram/ hari.Suplementasi PUFA omega-3 rantai panjang dosis rendah (400 mg/hari) dalam margarin tidak menurunkan konsentrasi TG secara bermakna. ${ }^{83}$ Faedah PUFA omega-3 terhadap mortalitas kardiovaskular berdasarkan berbagai studi tidak konsisten ${ }^{84}$ walau satu studi di Jepang melaporkan terapi EPA berhubungan dengan penurunan 19\% kejadian kardiovaskular. ${ }^{85}$

\section{Terapi Farmakologis Untuk Dislipidemia}

\section{I. Statin (inhibitor HMG-CoA reduktase)}

Statin adalah obat penurun lipid paling efektif untuk menurunkan kolesterol LDL dan terbukti aman tanpa efek samping yang berarti. Selain berfungsi untuk menurunkan kolesterol LDL, statin juga mempunyai efek meningkatkan kolesterol HDL dan menurunkan TG. Berbagai jenis statin dapat menurunkan kolesterol LDL 18-55\%, meningkatkan kolesterol HDL 5-15\%, dan menurunkan TG 7-30\%. Cara kerja statin adalah dengan menghambat kerja HMG-CoA reduktase. ${ }^{86}$ Efeknya dalam regulasi CETP menyebabkan penurunan konsentrasi kolesterol LDL dan VLDL. Di hepar, statin meningkatkan regulasi reseptor kolesterol LDL sehingga meningkatkan pembersihan kolesterol LDL. ${ }^{87}$ Dalam keadaan hipertrigliseridemia (tidak berlaku bagi normotrigliseridemia), statin membersihkan kolesterol VLDL. Mekanisme yang bertanggungjawab terhadap peningkatan konsentrasi kolesterol HDL oleh statin sampai sekarang belum jelas. ${ }^{88}$ Studi awal yang menggunakan statin untuk menurunkan kolesterol LDL menunjukkan penurunan laju PJK dan mortalitas total serta berkurangnya infark miokard, prosedur revaskularisasi, stroke, dan penyakit 
vaskular perifer. ${ }^{89-93}$ Statin hendaknya diresepkan sampai dosis maksimal yang direkomendasikan(Tabel 5) atau yang dapat ditoleransi untuk mencapai target kolesterol LDL.

Tabel 5. Dosis statin maksimal yang direkomendasikan

\begin{tabular}{lc}
\hline Statin & $\begin{array}{c}\text { Dosis maksimal yang } \\
\text { direkomendasikan }(\mathrm{mg} / \text { hari })\end{array}$ \\
\hline Lovastatin & 80 \\
Pravastatin & 80 \\
Simvastatin & 80 \\
Fluvastatin & 80 \\
Atorvastatin & 80 \\
Rosuvastatin & 40 \\
Pitavastatin & 4 \\
\hline
\end{tabular}

Pada tahun 2011, FDA Amerika Serikat mengeluarkan rekomendasi baru tentang keamanan simvastatin $80 \mathrm{mg} .{ }^{94}$ Simvastatin yang digunakan dengan dosis maksimum ( $80 \mathrm{mg}$ ) berhubungan dengan miopati atau jejas otot terutama jika digunakan selama 12 bulan berturutan. Simvastatin dosis $80 \mathrm{mg}$ tidak dianjurkan diresepkan bagi pasien baru,melainkan bagi mereka yang telah menggunakan dosis tersebut selama 12 bulan berturutan tanpa keluhan atau gejala miopati.

Bagi pasien dengan PGK, dosis statin perlu disesuaikan seperti yang tercantum dalam Tabel $\mathbf{6}$. dengan obat yang dimetabolisme melalui enzim tersebut.

Miopati, sebuah terminologi umum untuk penyakit otot, terjadi pada $5 \%$ pasien pengguna statin dan kejadiannya tidak berbeda dengan pengguna plasebo dalam penelitian klinis acak. ${ }^{98}$ Miopati dapat berupa mialgia, miositis, atau rabdomiolisis. Mialgia adalah terminologi untuk nyeri atau kelemahan otot tanpa peningkatan kreatinin kinase. Miositis terjadi jika keluhan otot disertai peningkatan kreatinin kinase. Sementara itu, rabdomiolisis merupakan diagnosis pada pasien dengan keluhan otot yang disertai peningkatan kreatinin kinase melebihi 10x batas atas normal. Pemeriksaan kreatinin kinase tanpa dasar keluhan otot tidak mempunyai nilai klinis sehingga tidak dianjurkan. Kejadian rabdomiolisis terjadi kurang dari 1 persejuta peresepan. Faktor risiko terjadinya miopati adalah: berat badan rendah, usia lebih dari 80 tahun, penyakit multiorgan terutama PGK, atau periode perioperatif. Miopati juga berhubungan dengan konsumsi atau obat yang spesifik seperti fibrat (terutama gemfibrozil), eritromisin, klaritromisin, antibiotika makrolid, antifungal, amiodaron, verapamil, siklosporin, jus anggur (sekitar 1 Liter perhari), dan minum alkohol berlebihan.

Peningkatan enzim hepar terjadi pada 0,5$2 \%$ pengguna statin terutama pada dosis tinggi. ${ }^{99}$ Setiap pasien hendaknya diperiksa enzim heparnya

Tabel 6. Penyesuaian dosis statin pada PGK ${ }^{95}$

\begin{tabular}{|l|c|c|c|c|}
\hline \multirow{2}{*}{ Statin } & \multicolumn{3}{|c|}{ Dosis pada PGK dalam mg/hari } \\
\cline { 2 - 5 } & $\begin{array}{c}\text { Tanpa PGK atau PGK } \\
\text { tingkat 1-2 }\end{array}$ & PGK tingkat 3 & PGK tingkat 3-4 & Transplan ginjal \\
\hline Atorvastatin & $10-80$ & $10-80$ & $10-80$ & $10-20$ \\
\hline Fluvastatin & $20-80$ & $20-80$ & $10-80$ & $10-80$ \\
\hline Lovastatin & $10-80$ & $10-80$ & $10-40$ & $10-40$ \\
\hline Pravastatin & $10-40$ & $10-40$ & $10-20$ & $10-20$ \\
\hline Rosuvastatin & $5-40$ & $5-20$ & $5-10$ & 5 \\
\hline Simvastatin & $5-40$ & $5-40$ & $5-20$ & $5-20$ \\
\hline
\end{tabular}

Dalam keadaan tidak toleran terhadap statin, direkomendasikan pemakaian bile acid sequestrant atau asam nikotinat, ${ }^{96,97}$ atau dapat dipertimbangkan pemakaian inhibitor absorpsi kolesterol (ezetimibe) tunggal atau dikombinasikan dengan asam nikotinat atau bile acid sequestrant. ${ }^{35}$

Semua statin kecuali pravastatin, rosuvastatin, dan pitavastatin mengalami metabolisme dihati melalui isoenzim sitokrom P450 sehingga akan berinteraksi sebelum memulai terapi statin dan sesuai indikasi sesudahnya. Terapi statin hendaknya dihentikan pada pasien dengan jejashepar serius yang disertai keluhan klinis dan/atau hiperbilirubinemia atau ikterus. ${ }^{100}$ Kenaikan transaminase lebih dari $3 \mathrm{x}$ batas atas normal merupakan indikasi untuk menghentikan terapi statin. Terapi statin dapat dilanjutkan jika konsentrasi transaminase sudah turun kurang dari $3 \mathrm{x}$ batas atas normal. 
Pengobatan statin berhubungan dengan terjadinya DM onset baru. ${ }^{101}$ Analisis meta dari 13 studi dengan 91140 partisipan menunjukkan pengobatan statin meningkatkan insidenDM sebesar 9\% dalam 4 tahun. Hubungan terapi statin dengan risiko DM lebih kuat pada partisipan usia tua sementara IMT dan persentase perubahan kolesterol LDL bukan faktor yang penting. Temuan ini tidak mengubah rekomendasi pengobatan statin pada pasien dengan risiko kardiovaskular tinggi dan menekankan pentingnya terapi intervensi gaya hidup bagi pasien dengan risiko rendah.

Statin meningkatkan risiko gangguan atau hilangnya memori pada pasien di atas usia 50 tahun yang reversibel ketika terapi statin dihentikan. Onset gangguan memori ini bisa bervariasi dari satu hari hingga beberapa tahun sesudah terapi statin dan tidak berhubungan dengan jenis statin tertentu, dosisnya, ataupun pengobatan tambahan. Gangguan memori ini tidak berhubungan dengan demensia yang menetap atau progresif seperti penyakit Alzheimer. ${ }^{100}$

Pada pasien dengan risiko tinggi dan sangat tinggi, sebaiknya terapi statin dilanjutkan walau target terapi sudah tercapai selama tidak ada indikasi kontra ataupun efek samping yang berat. ${ }^{102}$

\section{2. Inhibitor absorpsi kolesterol}

Ezetimibe merupakan obat penurun lipid pertama yang menghambat ambilan kolesterol dari diet dan kolesterol empedu tanpa mempengaruhi absorpsi nutrisi yang larut dalam lemak. Dosis ezetimibe yang direkomendasikan adalah $10 \mathrm{mg} /$ hari dan harus digunakan bersama statin, kecuali pada keadaan tidak toleran terhadap statin, di mana dapat dipergunakan secara tunggal. Tidak diperlukan penyesuaian dosis bagi pasien dengan gangguan hati ringan atau insufisiensi ginjal berat. Kombinasi statin dengan ezetimibe menurunkan kolesterol LDL lebih besar daripada menggandakan dosis statin. ${ }^{103}$ Kombinasi ezetimibe dan simvastatin telah diujikan pada subyek dengan stenosis aorta ${ }^{104} \mathrm{dan}$ pasien gagal ginjal kronik. ${ }^{105}$ Sampai saat ini belum ada laporan efek samping yang berarti dari pemakaian ezetimibe. ${ }^{105-}$ ${ }^{107}$ Sebelum ada hasil studi klinis yang lengkap, ezetimibe yang dikombinasikan dengan statin direkomendasikan sebagai obat penurun kolesterol LDL lini kedua jika target tidak tercapai dengan statin dosis maksimal. Pemakaian ezetimibe tunggal atau kombinasinya dengan bile acid sequestrant atau asam nikotinat dapat dipertimbangkan pada pasien yang tidak toleran terhadap statin. ${ }^{35}$ Penelitian yang mengevaluasi efek kombinasi ezetimibe dengan simvastatin pada saat ini sedang berlangsung. ${ }^{108}$

\section{3. Bile acid sequestrant}

Terdapat 3 jenis bile acid sequestrant yaitu kolestiramin, kolesevelam, dan kolestipol. Bile acid sequestrant mengikat asam empedu (bukan kolesterol) di usus sehingga menghambat sirkulasi entero-hepatik dari asam empedu dan meningkatkan perubahan kolesterol menjadi asam empedu di hati. Dosis harian kolestiramin, kolestipol, dan kolesevelam berturutan adalah 4-24 gram, 5-30 gram, dan 3,8-4,5 gram. Penggunaan dosis tinggi (24 g kolestiramin atau 20 $\mathrm{g}$ of kolestipol) menurunkan konsentrasi kolesterol LDL sebesar 18-25\%. Bile acid sequestrant tidak mempunyai efek terhadap kolesterol HDL sementara konsentrasiTG dapat meningkat. Walau tidak menurunkan kejadian infark miokard dan kematian akibat PJK dalam sebuah penelitian pencegahan primer, ${ }^{96}$ bile acid sequestrant direkomendasikan bagi pasien yang tidak toleran terhadap statin. ${ }^{35}$ Efek sampingnya terutama berkenaan dengan sistem pencernaan seperti rasa kenyang, terbentuknya gas, dan konstipasi. Bile acid sequestrant berinteraksi dengan obat lain seperti digoksin, warfarin, tiroksin, atau tiazid, sehingga obat-obatan tersebut hendaknya diminum 1 jam sebelum atau 4 jam sesudah bile acid sequestrant. Absorpsi vitamin $\mathrm{K}$ dihambat oleh bile acid sequestrant dengan akibat mudah terjadi perdarahan dan sensitisasi terhadap terapi warfarin.

\section{4. Fibrat}

Fibrat adalah agonis dari PPAR- $\alpha$. Melalui reseptor ini, fibrat menurunkan regulasi gen apoC-III serta meningkatkan regulasi gen apoA-I danAII. Berkurangnya sintesis apoC-III menyebabkan peningkatan katabolisme TG oleh lipoprotein lipase, berkurangnya pembentukan kolesterol VLDL, dan meningkatnya pembersihan kilomikron. Peningkatan regulasi apoA-I dan apoA-II menyebabkan meningkatnya konsentrasi kolesterol HDL. ${ }^{109}$ Sebuah analisis meta menunjukkan bahwa fibrat bermanfaat menurunkan kejadian kardiovaskular terutama jika diberikan pada pasien dengan konsentrasiTG diatas $200 \mathrm{mg} / \mathrm{dL} .{ }^{45}$ Terapi kombinasi fibrat (fenofibrat) dengan statin pada pasien DM tidak lebih baik dari terapi statin saja dalam menurunkan laju kejadian 
kardiovaskular kecuali jika konsentrasiTG lebih dari $200 \mathrm{mg} / \mathrm{dL}$, konsentrasi kolesterol LDL $\leq 84$ $\mathrm{mg} / \mathrm{dL}$, dan konsentrasi kolesterol HDL $\leq 34 \mathrm{mg} /$ dL. ${ }^{110}$ Penelitian ini memperkuat pendapat bahwa terapi penurunan konsentrasiTG ditujukan hanya pada pasien dengan risiko kardiovaskular tinggi yang konsentrasi kolesterol LDL-nya telah mencapai target dengan terapi statin dan konsentrasiTG-nya masih diatas $200 \mathrm{mg} / \mathrm{dL}$.

Fibrat dapat menyebabkan miopati, peningkatan enzim hepar, dan kolelitiasis. ${ }^{111}$ Risiko miopati lebih besar pada pasien dengan gagal ginjal kronik dan bervariasi menurut jenis fibrat. Gemfibrozil lebih berisiko menyebabkan miopati dibandingkan fenofibrat jika dikombinasikan dengan statin. ${ }^{4}$ Jika fibrat diberikan bersama statin maka sebaiknya waktu pemberiannya dipisah untuk mengurangi konsentrasi dosis puncak, misalnya: fibrat pada pagi dan statin pada sore hari. Dosis fenofibrat adalah $200 \mathrm{mg} / \mathrm{hari}$, dengan dosis maksimal $200 \mathrm{mg} /$ hari. Dosis gemfibrozil adalah $600 \mathrm{mg}$ diberikan 2 kali sehari, dengan dosis maksimal $1200 \mathrm{mg} /$ hari. $^{23}$

\section{5. Asam nikotinat (niasin)}

Asam nikotinat menghambat mobilisasi asam lemak bebas dari jaringan lemak perifer ke hepar sehingga sintesis TG dan sekresikolesterol VLDL di hepar berkurang. ${ }^{12}$ Asam nikotinat juga mencegah konversi kolesterol VLDL menjadi kolesterol LDL, ${ }^{113}$ mengubah kolesterol LDL dari partikel kecil (small, dense) menjadi partikel besar, dan menurunkan konsentrasi Lp(a). ${ }^{114}$ Asam nikotinat meningkatkan kolesterol HDL melalui stimulasi produksi apoA-I di hepar. ${ }^{115}$ Niasin yang digunakan saat ini terutama yang berbentuk extended release yang dianjurkan diminum sebelum tidur malam. Dosis awal yang direkomendasikan adalah $500 \mathrm{mg} /$ hari selama 4 minggu dan dinaikkan setiap 4 minggu berikutnya sebesar $500 \mathrm{mg}$ selama masih dapat ditoleransi sampai konsentrasi lipid yang dikehendaki tercapai. Dosis maksimum 2000 mg/hari menurunkanTG 20-40\%, kolesterol LDL 15-18\%, dan meningkatkan konsentrasi HDL 15-35\%. ${ }^{115}$

Menambahkan niasin pada terapi statin tidak memberikan keuntungan tambahan jika diberikan pada pasien dengan penyakit kardiovaskular aterosklerotik yang konsentrasi kolesterol LDL-nya kurang dari 70 $\mathrm{mg} / \mathrm{dL} \cdot{ }^{13}$ Sebuah studi yang menambahkan niasin extended release pada statin pada lebih dari 25.000 pasien dengan penyakit kardiovaskular gagal memperlihatkan keuntungan tambahan berupa penurunan laju serangan jantung atau stroke. . $^{14116}$

Alasan terbanyak menghentikan penggunaan niasin pada bulan pertama adalah efek samping berupa keluhan pada kulit (ruam, pruritis, flushing), keluhan gastrointestinal, DM, dan keluhan muskuloskeletal. ${ }^{14}$ Untuk mengurangi efek flushing, niasin dikombinasikan dengan laropripant, sebuah antagonis prostaglandin D2.

\section{6. Inhibitor CETP}

Cholesteryl ester transfer proteinberfungsi membantu transfer cholesteryl ester dari kolesterol HDL kepada VLDL dan LDL yang selanjutnya akan dibersihkan dari sirkulasi melalui reseptor LDL di hepar. Terapi dengan inhibitor CETP mempunyai efek ganda yaitu meningkatkan konsentrasi kolesterol HDL dan menurunkan konsentrasi kolesterol LDL melalui reversed cholesterol transport. Inhibitor CETP dapat bersifat proaterogenik jika cholesteryl ester dari kolesterol VLDL atau LDL diambil oleh makrofag. Sebaliknya, jika cholesteryl ester diambil oleh hepar melalui reseptor LDL, inhibitor CETP bersifat antiaterogenik. ${ }^{117}$ Diantara 3 inhibitor CETP (torcetrapib, dalcetrapib dan anacetrapib), torcetrapib telah ditarik dari pasaran karena meningkatkan kematian. ${ }^{12}$ Monoterapi anacetrapib $40 \mathrm{mg}, 150$ $\mathrm{mg}$, atau $300 \mathrm{mg}$ selama 8 minggu menurunkan konsentrasi kolesterol LDL berturutan sebesar 16\%, 27\%, 40\%, dan 39\% serta meningkatkan konsentrasi kolesterol HDL berturutan sebesar 44\%, 86\%, 139\%, dan $133 \% .{ }^{118}$ Sebuah penelitian fase III dengan anacetrapib: Randomized EValuation of the Effects of Anacetrapib through Lipid-modification (REVEAL) saat ini sedang berjalan.

\section{7. Aferesis kolesterol LDL}

Tindakan aferesis ditujukan bagi pasien dengan $\mathrm{HoFH}$ atau $\mathrm{HeFH}$ berat. Dengan teknik yang mahal tetapi efektif ini, kolesterol LDL dan Lp(a) dibuang dari plasma selama dilakukan sirkulasi ekstrakorporeal setiap 1 atau 2 minggu sekali. ${ }^{35}$

\section{8. Terapi kombinasi}

Terapi kombinasi dapat dipertimbangkan bagi pasien yang target kolesterol LDL-nya tidak tercapai dengan terapi statin dosis tinggi atau bagi pasien yang tidak 
toleran terhadap statin. Kombinasi statin dan bile acid sequestrant dapat memperkuat penurunan kolesterol LDL sebesar $10-20 \%$ dibandingkan dengan terapi statin tunggal. Terapi kombinasi ini dilaporkan menurunkan laju aterosklerosis yang dideteksi dengan angiografi. ${ }^{119,120}$ Menggabungkan tablet berisi fitosterol dengan statin diikuti oleh penurunan kolesterol LDL 5-10\% lebih besar. ${ }^{75}$ Seperti telah disebutkan terdahulu, menambahkan ezetimibe pada statin menurunkan kolesterol LDL lebih besar daripada menggandakan dosis statin. ${ }^{103}$ Terapi kombinasi antara ezetimibe dengan bile acid sequestrant atau dengan asam nikotinat menyebabkan penurunan konsentrasi kolesterol LDL lebih besar dibandingkan penggunaan obat tunggal. Walau demikian, belum ada evaluasi luaran klinis dari terapi kombinasi tersebut.

Kombinasi fibrat (terutama fenofibrat, bezafibrat, dan cipofibrat) dengan statin menurunkan konsentrasi kolesterol LDL dan TG serta meningkatkan kolesterol HDL lebih tinggi daripada terapi tunggal manapun. ${ }^{121}$ Walau demikian, studi luaran klinis tidak menunjukkan keunggulan dibandingkan dengan penggunaan statin monoterapi. ${ }^{43,44,110}$ Kombinasi statin dan fibrat meningkatkan risiko miopati, terutama jika fibrat digunakan dengan statin dosis tinggi atau statin dikombinasikan dengan gemfibrozil. Kombinasi asam nikotinat yang extended releasedengan statin dosis moderat meningkatkan konsentrasi kolesterol HDL dan menurunkan konsentrasi TG lebih besar daripada statin dosis tinggi atau kombinasi asam nikotinat dengan ezetimibe. ${ }^{122}$ Menambahkan niasin pada terapi statin tidak memberikan keuntungan tambahan dibandingkan dengan terapi statin tunggal jika diberikan pada pasien dengan penyakit kardiovaskular aterosklerotik yang kadar kolesterol LDL-nya kurang dari 70 mg/ dL. ${ }^{13}$ Sebuah studi lain yang mengikutsertakan lebih dari 25.000 pasien dengan penyakit kardiovaskular gagal membuktikan keuntungan tambahan dengan menambahkan niasin extended release pada statin dalam menurunkan laju serangan jantung atau stroke. ${ }^{116}$

\section{Tatalaksana Dislipidemia pada Situasi Khusus}

\section{I. Dislipidemia familial}

Konsentrasi lipid plasma sangat dipengaruhi oleh faktor genetik yang dalam keadaan ekstrem dimanifestasikan sebagai dislipidemia familial dimana ditemukan konsentrasi kolesterol LDL atau TG yang tinggi, atau konsentrasi kolesterol HDL yang rendah pada beberapa anggota keluarga. Keberadaan dislipidemia familial patut dicurigai pada pria usia $<50$ tahun atau wanita $<60$ tahun dengan penyakit kardiovaskular. Pasien dengan dislipidemia familial dikategorikan mempunyai risiko kardiovaskular tinggi. ${ }^{35}$ Estimasi risiko kardiovaskular berdasarkan persamaan risiko multivariat saja tidaklah mencukupi untuk estimasi risiko pasien dengan dislipidemia familial.

Terapi statin intensitas tinggi dianjurkan bagi pasien dengan dislipidemia familial untuk menurunkan konsentrasi kolesterol LDL lebih dari 50\%. ${ }^{123}$ Anak dari orang tua dengan dislipidemia familial hendaknya menerapkan pola diet sejak awal dan mendapat terapi farmakologis saat beranjak dewasa. ${ }^{35}$

Familial Combined Hyperlipidemia ditandai oleh peningkatan konsentrasi kolesterol LDL, TG, atau keduanya. Dalam praktik klinis, identifikasi pasien dengan FCH dilakukan dengan mengidentifikasi adanya kombinasi apoB $>120 \mathrm{mg} / \mathrm{dL}$ dan TG $>133$ $\mathrm{mg} / \mathrm{dL}$ pada pasien dengan riwayat PJK prematur dalam keluarga. ${ }^{124}$ Kelainan ini merupakan hiperlipidemia genetik yang tersering dijumpai di populasi dengan perkiraan prevalensi $0,5 \%-2 \% .{ }^{125}$ Diagnosis banding FCH adalah sindrom metabolik. Terapi statin pada pasien dengan $\mathrm{FCH}$ terbukti dapat menurunkan risiko kardiovaskular.

Heterozygous Familial Hypercholesterolemia adalah kelainan genetik yang ditandai oleh peningkatan konsentrasi kolesterol LDL (200-400 mg/dL) akibat mutasi reseptor kolesterol LDL. Pada umumnya, konsentrasi TG dalam batas normal tetapi dapat meningkat pada pasien dengan obesitas. Statin merupakan obat pilihan bagi pasien dengan $\mathrm{HeFH}$. Target terapi pengobatan statin adalah menurunkan konsentrasi kolesterol LDL minimal 50\% ${ }^{123}$ atau sesuai dengan tingkat risiko kardiovaskularnya. ${ }^{35}$ Kombinasi statin dengan ezetimibe direkomendasikan bagi pasien yang target kolesterolnya LDL tidak tercapai dengan statin dosis maksimal. Ezetimibe monoterapi direkomendasikan bagi pasien yang tidak toleran atau mempunyai indikasi kontra terhadap statin. Terapi dengan bile acid sequestrant, asam nikotinat, atau fibrat dapat dipertimbangkan bagi pasien yang tidak toleran terhadap statin dan ezetimibe. ${ }^{123}$

Dislipidemia lain yang jarang terjadi adalah HoFH, familial dysbetalipoproteinemia, dan defisiensi lipoprotein lipase familial (Tabel 7). 
Jurnal Kardiologi Indonesia

Tabel 7. Berbagai kelainan metabolisme lipoprotein genetik ${ }^{35}$

\begin{tabular}{|c|c|c|c|}
\hline Nama & Prevalensi & Gen terkait & Pengaruh terhadap lipoprotein \\
\hline $\mathrm{HeFH}$ & $1: 500$ & $\begin{array}{l}\text { LDLR } \\
\text { PCSK } 9 \\
\text { ApoB }\end{array}$ & 个LDL \\
\hline $\mathrm{HoFH}$ & $1: 1000000$ & LDLR & ヘ个LDL \\
\hline $\mathrm{FCH}$ & $1: 100 / 200$ & USF I + modifying genes & 个LDL,VLDL, apoB \\
\hline Dysbetalipoproteinemia familial & $1: 5000$ & ApoE & 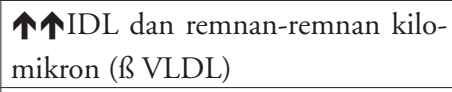 \\
\hline Defisiensi lipase lipoprotein familial & $1: 1000000$ & $\begin{array}{l}\text { LPL } \\
\text { ApoC-II }\end{array}$ & ヤ个Kilomikron, VLDL \\
\hline $\begin{array}{l}\text { Penyakit Tangier (analphalipoprotein- } \\
\text { aemia) }\end{array}$ & $1: 1000000$ & ABC-I & $\downarrow \downarrow$ HDL \\
\hline Defisiensi LCAT familial (fish eye disease) & $1: 1000000$ & LCAT & $\downarrow$ HDL \\
\hline
\end{tabular}

\section{2. Wanita}

Informasi tentang efek statin, terutama untuk pencegahan primer, pada wanita sangat terbatas. Sebuah analisis meta menunjukkan laju kejadian kardiovaskular lebih rendah pada wanita yang diterapi statin daripada yang mendapat plasebo baik pada pencegahan primer maupun sekunder. ${ }^{126}$ Oleh karena itu, terapi statin hendaknya digunakan tanpa memandang jenis kelamin. Walau data tentang efek pengobatan nonstatin belum tersedia, penggunaan obat seperti niasin, fibrat, dan ezetimibe monoterapi atau dikombinasikan dengan statin tetap direkomendasikan pada wanita. Semua obat penurun lipid tidak boleh diberikan kepada wanita yang merencanakan kehamilan, selama kehamilan, dan menyusui.

\section{3. Usia lanjut}

Sebagian terbesar penelitian yang menggunakan statin mencakup subyek usia muda kurang dari 65 tahun. Kelompok usia lanjut menjadi penting karena proporsinya meningkat dengan meningkatnya usia harapan hidup dan mereka relatif mempunyai risiko kardiovaskular lebih tinggi karena terpapar dengan faktor risiko lebih lama. Selain itu, efek samping statin berupa miopati lebih sering terjadi pada pasien berusia lanjut karena menggunakan lebih banyak obat yang dimetabolisme di sitokrom P450.

Data dari studi pencegahan sekunder menunjukkan bahwa terapi statin menurunkan risiko kardiovaskular lebih besar pada subyek usia $\geq 65$ tahun daripada usia lebih muda. ${ }^{127,128}$ Sebuah studi pencegahan primer dan sekunder pada subyek usia rerata 75 tahun dengan risiko kardiovaskular tinggi menunjukkan bahwa terapi statin selama 3 tahun berhubungan dengan penurunan kejadian kardiovaskular tanpa mempengaruhi mortalitas total dan disfungsi kognitif. Risiko kardiovaskular tinggi pada penelitian ini diartikan sebagai penyakit vaskular (koroner, serebral, atau periferal) atau mempunyai risiko untuk penyakit vaskular seperti merokok, hipertensi, atau DM. ${ }^{129}$ Berdasarkan data yang tersedia, terapi penurun lipid (statin) pada pasien usia lanjut dengan riwayat penyakit kardiovaskular hendaknya diperlakukan sama seperti pasien berusia muda. Sementara itu, terapi statin dapat dipertimbangkan bagi pasien usia lanjut yang mempunyai setidaknya 1 faktor risiko kardiovaskular. Untuk menghindari efek samping, terutama miopati, statin pada pasien usia lanjut sebaiknya dititrasi dari dosis kecil menuju ke dosis yang dapat menurunkan konsentrasi kolesterol LDL yang dikehendaki.

\section{4. Sindrom metabolik dan DM}

Sindrom metabolik adalah sejumlah faktor risiko terjadinya penyakit kardiovaskular dan DM tipe 2 yang terjadi bersamaan secara tidak kebetulan. Diagnosis sindrom metabolik dapat ditegakkan jika terdapat 3 atau lebih faktor risiko berupaobesitas sentral, peningkatan tekanan darah, dislipidemia (peningkatan konsentrasi TG dan penurunan konsentrasikolesterol HDL), dan peningkatan konsentrasi gula darah puasa. ${ }^{130}$ Pada wanita $\geq 65$ tahun, keberadaan sindrom metabolik bersama DM meningkatkan kematian kardiovaskular sebesar 2-3 kali, melebihi kematian yang berhubungan dengan komponen tunggalnya. 
Memasukkan dislipidemia kedalam definisi tidak memperkuat hubungan ini. ${ }^{131}$ Tidak diketahui apakah hubungan sindrom metabolik dengan risiko kardiovaskular melebihi risiko yang berhubungan dengan penjumlahan komponennya. Sindrom metabolik berhubungan dengan peningkatan luaran kardiovaskular sebesar 2 kali dan kematian total sebesar 1,5 kali. ${ }^{132}$

Peningkatan kolesterol VLDL yang menyebabkan kolesterol LDL menjadi lebih aterogenik merupakan dislipidemia utama pada sindrom metabolik dan juga pada DM tipe 2. ${ }^{133}$ Peningkatan TG dan penurunan konsentrasi kolesterol HDL ditemukan pada sekitar 50\% penderita DM tipe $2 .{ }^{134}$ Pasien dengan DM tipe 1 yang terkontrol konsentrasi gula darahnya juga berpotensi mengalami perubahan aterogenik dari partikel LDL walau mempunyai konsentrasi kolesterol LDL dan TG dibawah normal. Profil lipid yang normal pada pasienDM tipe 1 berhubungan dengan aktivasi lipoprotein lipase akibat terapi insulin. ${ }^{35}$

Strategi pengobatan pasien sindrom metabolik dan DM tipe 2 mengikuti tatalaksana dislipidemia bagi pasien risiko tinggi dan sangat tinggi. Mengingat kelemahan studi yang menyatakan intervensi gaya hidup secara intensif gagal menurunkan kejadian kardiovaskular pada pasien DM tipe 2 dengan obesitas, ${ }^{69}$ maka terapi intervensi gaya hidup untuk memperbaiki profil lipid aterogenik direkomendasikan bagi semua pasien dengan sindrom metabolik dan DM tipe $2 .{ }^{135}$

Terapi penurunan konsentrasi kolesterol LDL dengan statin pada pasien DM tipe 2 terbukti menurunkan kejadian kardiovaskular secara bermakna. ${ }^{136}$ Penelitian mengenai efektivitas pengobatan dengan statin untuk mencegah komplikasi kardiovaskular dan ginjal pada remaja denganDM tipe 1 saat ini sedang berjalan. ${ }^{137}$

\section{5. Penyakit ginjal}

Insiden penyakit jantung aterosklerosis sangat tinggi pada pasien dengan PGK sehingga mereka dengan GFR $<60 \mathrm{~mL} / \mathrm{menit} / 1,73 \mathrm{~m}^{2}$ dikategorikan sebagai berisiko kardiovaskular sangat tinggi, ekuivalen dengan PJK. ${ }^{35,138}$ Tatalaksana dislipidemia pasien dengan GFR $<60 \mathrm{~mL} / \mathrm{menit} / 1,73 \mathrm{~m}^{2}$ mengikuti tatalaksana pasien dengan risiko kardiovaskular sangat tinggi. Penurunan kolesterol LDL ke konsentrasi 60-70 $\mathrm{mg} / \mathrm{dL}$ dengan statin maupun kombinasi statin dengan ezetimibe pada pasien gagal ginjal kronik yang menjalani hemodialisis tidak menurunkan kejadian kardiovaskular. ${ }^{105,139,140} \mathrm{Pada}$ pasien PGK dengan GFR $<60 \mathrm{~mL} / \mathrm{menit} / 1,73 \mathrm{~m}^{2}$ (rerata $26,6 \mathrm{~mL} /$ menit $/ 1,73 \mathrm{~m}^{2}$ )yang tidak menjalani hemodialisis, penurunan kolesterol LDL dengan kombinasi statin dan ezetimibe menurunkan kejadian aterosklerotik mayor secara bermakna dan tidak mengakibatkan perburukan fungsi ginjal. ${ }^{105}$ Mengingat hasil dari studi luaran klinis diatas, direkomendasikan pemberian statin atau statin/ezetimibe untuk menurunkan kejadian aterosklerotik mayor bagi pasien gagal ginjal kronik (termasuk yang menjalani transplantasi ginjal) kecuali jika pasien tersebut menjalani dialisis. ${ }^{95}$

Dosis berbagai obat penurun lipid perlu disesuaikan dengan beratnya gagal ginjal kronik kecuali atorvastatin, fluvastatin, bile acid sequestrant, dan ezetimibe (Tabel 8). ${ }^{95}$ Tabel 9 menunjukkan stadium PGK. ${ }^{141}$

\section{6. Stroke}

Pasien dengan riwayat stroke dan TIA dikategorikan kedalam kelompok dengan risiko kardiovaskular sangat tinggi. ${ }^{35}$ Etiologi stroke bervariasiseperti tromboemboli (sering berhubungan dengan fibrilasi atrium), aterosklerosis arteri karotis, penyakit serebrovaskular yang mengenai pembuluh darah kecil, dan perdarahan intrakranial (perdarahan intraserebral dan subarakhnoid). Hubungan dislipidemia dengan kejadian aterotrombotik pada pasien stroke iskemik dan TIA sudah ketahui, sementara hubungannya dengan jenis stroke lainnya belum diketahui dengan jelas. Hubungan antara konsentrasi lipid rendah dengan peningkatan insiden stroke perdarahan hanya dibuktikan oleh studi observasional dan tidak konsisten. ${ }^{142-146}$ Terapi penurun lipid pada pasien dengan risiko kardiovaskular tinggi menurunkan angka kejadian stroke dan TIA ${ }^{129,147-149}$ sehingga terapi statin pada pasien dengan risiko kardiovaskular tinggi ditujukan untuk pencegahan primer stroke dan menurunkan risiko kejadian kardiovaskular lainnya. Peran obat penurun lipid selain statin untuk pencegahan primer stroke dan TIA belum jelas. Peran statin dalam pencegahan sekunder stroke tergantung dari jenis strokenya. Pasien yang mengalami kejadian serebrovaskular akibat proses aterotrombosis mendapat faedah terbesar dari pengobatan statin. Sementara itu, pasien dengan stroke perdarahan tidak mendapat manfaat dari terapi statin atau bahkan dapat berbahaya. ${ }^{148,150}$ 
Tabel 8. Penyesuaian dosis obat penurun lipid pada pasien gagal ginjal kronik

\begin{tabular}{|l|c|c|c|c|}
\hline Kelas dan Jenis Obat & $\begin{array}{c}\text { Tanpa PGK atau sta- } \\
\text { dium 1-2 }\end{array}$ & PGK stadium 3 & PGK stadium 4-5 & Transplan ginjal \\
\hline Statin (mg/hari) & & & & $10-80$ \\
\hline Atorvastatin & $10-80$ & $10-80$ & $10-80$ & $10-20$ \\
\hline Fluvastatin & $20-80$ & $20-80$ & $10-40$ & $10-80$ \\
\hline Lovastatin & $10-80$ & $10-80$ & $10-20$ & $10-40$ \\
\hline Pravastatin & $10-40$ & $10-40$ & $5-10$ & 5 \\
\hline Rosuvastatin & $5-40$ & $5-20$ & $5-20$ & $5-20$ \\
\hline Simvastatin & $5-40$ & $5-40$ & & $5-30$ \\
\hline Bile acid sequestrant (g/hari) & & & $4-16$ & $4-16$ \\
\hline Kolestipol & $5-30$ & $5-30$ & $2,6-3,8$ & $2,6-3,8$ \\
\hline Kolestiramin & $4-16$ & $4-16$ & & Hindari \\
\hline Kolesevelam & $2,6-3,8$ & $2,6-3,8$ & 500 & Hindari \\
\hline Derivat asam fibrat (mg/hari) & & & Hindari & Tidak diketahui \\
\hline Bezafibrat & $400-600$ & 200 & Hindari & Hindari \\
\hline Clofibrat & $1000-2000$ & 500 & 600 & 600 \\
\hline Ciprofibrat & 200 & Tidak diketahui & & \\
\hline Fenofibrat & 96 & 48 & 10 & Tidak diketahui \\
\hline Gemfibrozil & 1200 & 1200 & 1000 & Tidak diketahui \\
\hline Lainnya (mg/hari) & & 10 & & \\
\hline Ezetimibe & 10 & 2000 & & \\
\hline Niasin & 2000 & & & \\
\hline
\end{tabular}

Tabel 9. Klasifikasi beratnya PGK

\begin{tabular}{|l|l|l|}
\hline Stadium & Deskripsi & GFR $\left(\mathrm{mL} / \mathrm{menit} / 1,73 \mathrm{~m}^{2}\right)$ \\
\hline 1 & Kerusakan ginjal, GFR normal atau meningkat & $\geq 90$ \\
\hline 2 & Kerusakan ginjal, penurunan GFR ringan & $60-89$ \\
\hline 3 & Penurunan GFR moderat & $30-59$ \\
\hline 4 & Penurunan GFR berat & $15-29$ \\
\hline 5 & Gagal ginjal & $<15$ atau dialisis \\
\hline
\end{tabular}

\section{7. Sindrom koroner akut dan intervensi koroner perkutan}

Pasien sindrom koroner akut berisiko mengalami kejadian kardiovaskular berulang. Data penelitian klinis mendukung penurunan kolesterol LDL dengan statin secepatnya dan agresif untuk menurunkan morbiditas dan mortalitas kardiovaskular. ${ }^{151}$ Statin dosis tinggi direkomendasikan diberikan pada hari 1-4 perawatan sindrom koroner akut dan ditujukan untuk menurunkan konsentrasi kolesterol LDL menjadi $<70 \mathrm{mg} / \mathrm{dL}$ bagi pasien dengan konsentrasi kolesterol LDL awal $\geq 70 \mathrm{mg} / \mathrm{dL}$. Profil lipid perlu diperiksa ulang 4-6 minggu kemudian untuk evaluasi pencapaian target kolesterol LDL. ${ }^{35}$ Terapi statin tetap dianjurkan walau konsentrasi kolesterol LDL awal $<70$ $\mathrm{mg} / \mathrm{dL} .{ }^{35,152}$ Penelitian klinis dengan menggunakan
PUFA omega-3 pada pasien sindrom koroner akut tidak menurunkan kematian secara konsisten. ${ }^{83,153}$ Penurunan kematian pada pasien yang diterapi dengan PUFA omega-3 bukan disebabkan oleh efek antilipid melainkan oleh efek antiaritmia, terutama pada pasien dengan disfungsi ventrikel kiri. ${ }^{153}$

Terapi statin dengan dosis beban (loading dose) dalam jangka pendek yang diberikan sebelum intervensi koroner perkutan pada pasien angina stabil atau sindrom koroner akut berpotensi menurunkan kejadian infark miokard pasca prosedural dan kematian tanpa memandang apakah pasien telah mendapatkan terapi statin jangka panjang sebelumnya. ${ }^{154-156}$ Studi yang mengevaluasi efektivitas terapi statin dosis beban periprosedural pada luaran klinis hanya mengikutsertakan sedikit pasien. Waktu pemberian terapi dosis beban bervariasi antara 1 hingga 7 hari 
sebelum intervensi koroner perkutan. ${ }^{154,157}$ Berdasarkan studi terapi statin dosis beban periprosedural maka terapi ini dapat dipertimbangkan walau pasien telah mendapatkan terapi statin sebelumnya.

\section{Ucapan Terima Kasih}

Pengurus Pusat PERKI dengan ini mengucapkan terima kasih kepada PT. Merck, Sharp and Dohme, TBK dan Centra Communications serta pihak lain yang telah berkontribusi dan memberikan bantuannya dalam pembuatan Pedoman Tatalaksana Dislipidemia PERKI 2013 ini hingga selesai, ketua Pengurus Pusat PERKI, Prof. DR. Rochmad Romdoni, dr. SpPD(K), SpJP(K), FIHA, FasCC, FACC.

\section{Daftar Pustaka}

1. WHO. World Health Stastistics. 2007.

2. Hokanson J E, Austin MA. Plasma triglyceride level is a risk factor for cardiovascular disease independent of high-density lipoprotein cholesterol level: a metaanalysis of population-based prospective studies. J Cardiovasc Risk 1996;3:213-9.

3. Gordon T, Castelli WP, Hjortland MC, Kannel WB, Dawber TR. High Density Lipoprotein As a Protective Factor Against Coronary Heart Disease. The Framingham Study. Am J Med 1977;62:707-14.

4. Karthikeyan G, Teo KK, Islam S, McQueen MJ, Pais P, Wang X, Sato H, Lang CC, Sitthi-Amorn C, Pandey MR, Kazmi K, Sanderson JE, Yusuf S. Lipid Profile, Plasma Apolipoproteins, and Risk of a First Myocardial Infarction Among Asians: An Analysis From the INTERHEART Study. J Am Coll Cardiol 2009;53:244-53.

5. Asia Pacific Cohort Studies Collaboration. Cholesterol, Coronary Heart Disease and Stroke in the Asia Pacific Region. Int J Epidemiol 2003;32:563-72.

6. Yusuf S, Hawken S, Ounpuu S, Dans T, Avezum A, Lanas F, McQueen M, Budaj A, Pais P, Varigos J, Lisheng L; INTERHEART Study Investigators. Effect of potentially modifiable risk factors associated with myocardial infarction in 52 countries (the INTERHEART Study): case-control study. Lancet 2004;364:937-52.

7. Tim Biomedis Riset Kesehatan Dasar, Badan Penelitian dan Pengembangan Kesehatan Kementrian Kesehatan Republik Indonesia. Laporan Riset Kesehatan Dasar (Riskesdas) Bidang Biomedis. 2010:20-5.

8. Steg P G, Bhatt DL, Wilson PW, D’Agostino R Sr, Ohman EM, Röther J, Liau CS, Hirsch AT, Mas JL, Ikeda Y, Pencina MJ, Goto S; REACH Registry Investigators. One-Year Cardio- vascular Event Rates in Outpatients With Atherothrombosis. JAMA 2007;297.

9. Cholesterol Treatment Trialists' (CTT) Collaboration. Efficacy and safety of more intensive lowering of LDL cholesterol: a metaanalysis of data from 170000 participants in 26 randomised trials. Lancet 2010;376:1670-81.

10. Barter P, Gotto AM, LaRosa JC, Maroni J, Szarek M, Grundy SM, Kastelein JJ, Bittner V, Fruchart JC. Treating to New Targets Investigators. HDL cholesterol, very low levels of LDL cholesterol, and cardiovascular events. N Engl J Med 2007;357:130110.

11. Rubins H B, Robins SJ, Collins D, Fye CL, Anderson JW, Elam MB, Faas FH, Linares E, Schaefer EJ, Schectman G, Wilt TJ, Wiites J. Veterans Affairs High-Density Lipoprotein Cholesterol Intervention Trial Study Group. Gemfibrozil for the secondary prevention of coronary heart disease in men with low levels of high-density lipoprotein cholesterol. N Engl J Med 1999;341:410-8.

12. Barter P J, Caulfield M, Eriksson M, Grundy SM, Kastelein JP, Komajda M, Lopez-Sendon J, Mosca L, Tardif JC, Waters DD, Shear CL, Revkin JH, Buhr KA, Fisher MR, Tall AR, Brewer B. ILLUMINATE investigators. Effects of torcetrapib in patients at high risk for coronary events. N Engl J Med 2007;357:210922.

13. The AIM-HIGH Investigators. Niacin in Patients with Low HDL Cholesterol Levels Receiving Intensive Statin Therapy. N Engl J Med 2011;365:2255-67.

14. HPS2-THRIVE Collaborative Group. HPS2-THRIVE randomized placebo-controlled trial in 25673 high-risk patients of ER niacin/laropiprant: trial design, pre-specified muscle and liver outcomes, and reasons for stopping study treatment. Eur Heart J 2013;34:1279-91.

15. Triglyceride Coronary Disease Genetics Consortium and Emerging Risk Factors Collaboration, Sarwar N, Sandhu MS, Ricketts SL, Butterworth AS, Di Angelantonio E, Boekholdt SM, Ouwehand W, Watkins H, Samani NJ, Saleheen D, Lawlor D, Reilly MP, Hingorani AD, Talmud PJ, Danesh J. Triglyceridemediated pathways and coronary disease: collaborative analysis of 101 studies. Lancet 2010;375:1634-9.

16. Bansal S, Buring JE, Rifai N, Mora S, Sacks FM, Ridker PM. Fasting compared with nonfasting triglycerides and risk of cardiovascular events in women. JAMA 2007;298:309-16.

17. Nordestgaard B G, Benn M, Schnohr P, Tybjaerg-Hansen A. Nonfasting triglycerides and risk of myocardial infarction, ischemic heart disease, and death in men and women. JAMA 2007;298:299-308.

18. Pischon T, Girman CJ, Sacks FM, Rifai N, Stampfer MJ, Rimm EB. Non-high-density lipoprotein cholesterol and apolipoprotein $\mathrm{B}$ in the prediction of coronary heart disease in men. Circulation 2005;112:3375-83. 


\section{Jurnal Kardiologi Indonesia}

19. Ridker P M, Rifai N, Cook NR, Bradwin G, Buring JE. NonHDL cholesterol, apolipoproteins A-I and B100, standard lipid measures, lipid ratios, and CRP as risk factors for cardiovascular disease in women. JAMA 2005;294:326-33.

20. Sniderman A D, Furberg CD, Keech A, Roeters van Lennep JE, Frohlich J, Jungner I, Walldius G. Apolipoprotein versus lipids as indices of coronary risk and as targets for statin therapy treatment. Lancet 2003;361:777-80.

21. Robinson J G, Wang S, Smith BJ, Jacobson TA. Meta-analysis of the relationship between non-high-density lipoprotein cholesterol reduction and coronary heart disease risk. J Am Coll Cardiol 2009;53:316-22.

22. The Emerging Risk Factors Collaboration. Major lipids apolipoproteins, and risk of vascular disease. JAMA 2009;302:19932000.

23. Grundy S M, Becker D, Clark LT, Cooper RS, Denke MA, Howard WmJ, Hunninghake DB, Illingworth DR, Luepker RV, McBride P, McKenney JM, Pasternak RC, Stone NJ, Horn LV. National Cholesterol Education Program (NCEP) Expert Panel on Detection Evaluation and Treatment of High Blood Cholesterol in Adults (Adult Treatment Panel III). Third Report of the National Cholesterol Education Program (NCEP) Expert Panel on Detection, Evaluation, and Treatment of High Blood Cholesterol in Adults (Adult Treatment Panel III): Final Report. Washington, DC: National Institutes of Health, National Heart, Lung, and Blood Institute 2002; NIH Publication No.02:5215.

24. Taskinen M R, Barter PJ, Ehnholm C, Sullivan DR, Mann K, Simes J, Best JD, Hamwood S, Keech AC on behalf of the FIELD Study Investigators. Ability of traditional lipid ratios and apolipoprotein ratios to predict cardiovascular risk in people with type 2 diabetes. Diabetologia 2010;53:1846-55.

25. Erqou S, Kaptoge S, Perry PL, Di AE, Thompson A, White IR, Marcovina SM, Collins R, Thompson SG, Danesh J. Lipoprotein(a) concentration and the risk of coronary heart disease, stroke, and nonvascular mortality. JAMA 2009;302:41223.

26. Barlera S, Franzosi MG, Rust S, Bennett D, Silveira A, Malarstig A, Green FR, Lathrop M, Gigante B, Leander K, de FU, Seedorf U, Hamsten A, Collins R, Watkins H, Farrall M. Genetic variants associated with $\mathrm{Lp}(\mathrm{a})$ lipoprotein level and coronary disease. N Engl J Med 2009;361:2518-28.

27. Greene D J, Skeggs JW, Morton RE. Elevated triglyceride content diminishes the capacity of high density lipoprotein to deliver cholesteryl esters via the scavenger receptor class B type I (SR-BI). J Biol Chem 2001;276:4804-11.

28. Skeggs J W, Morton RE. LDL and HDL enriched in triglyceride promote abnormal cholesterol transport. J Lipid Res 2002;43:1264-74.

29. Chait A, Brazg RL, Tribble DL, Krauss RM. Susceptibility of small, dense, low-density lipoproteins to oxidative modification in subjects with the atherogenic lipoprotein phenotype, pattern B. Am J Med 1993;94:350-6.

30. Kwiterovich P OJ. Clinical relevance of the biochemical, metabolic, and genetic factors that influence low-density lipoprotein heterogeneity. Am J Cardiol 2002;90.

31. Ip S, Lichtenstein AH, Chung M, Lau J, Balk EM. Systematic review: association of low-density lipoprotein subfractions with cardiovascular outcomes. Ann Intern Med 2009;150:474-84.

32. Friedewald W T, Levy RI, Frederickson DS. Estimation of the concentration of low-density lipoprotein cholesterol in plasma, without use of the preparative ultracentrifuge. Clin Chem 1972;18:499-502.

33. Conroy R, Pyorala K, Fitzgerald AP, Sans S, Menotti A, De Backer G, De Bacquer D, Ducimetie`re P, Jousilahti P, Keil U, Njølstad I, Oganov RG, Thomsen T, Tunstall-Pedoe H, Tverdal A, Wedel H, Whincup P, Wilhelmsen L, Graham I. Estimation of ten-year risk of fatal cardiovascular disease in Europe: the SCORE project. Eur Heart J 2003;24:987-1003.

34. D’Agostino R BS, Vasan RS, Pencina MJ, Wolf PA, Cobain M, Massaro JM, Kannel WB. General cardiovascular risk profile for use in primary care: the Framingham Heart Study. Circulation 2008;117:743-53.

35. Reiner Z, Catapano AL, De Backer G, Graham I, Taskinen MR, Wiklund O, Agewall S, Alegria E, Chapman MJ, Durrington P, Erdine S, Halcox J, Hobbs R, JKjekshus J, Filardi PP, Riccardi G, Storey RF, Wood D for The Task Force for the management of dyslipidaemias of the European Society of Cardiology (ESC) and the European Atherosclerosis Society (EAS). ESC/EAS Guidelines for the management of dyslipidaemias. Eur Heart J 2011;32:1769-818.

36. Grundy S M, Cleeman JI, Merz CN, Brewer HB Jr, Clark LT, Hunninghake DB, Pasternak RC, Smith SC Jr, Stone NJ; for the Coordinating Committee of the National Cholesterol Education Program. Implications of recent clinical trials for the National Cholesterol Education Program Adult Treatment Panel III guidelines. Circulation 2004;110:227-39, 763 (correction).

37. Law M R, Wald NJ, Thompson SG. By how much and how quickly does reduction in serum cholesterol concentration lower risk of ischaemic heart disease? BMJ 1994;308:367-72.

38. Law M R. Lowering heart disease risk with cholesterol reduction: evidence from observational studies and clinical trials. Eur Heart J Suppl 1999;Suppl S:S3-S8.

39. Lipid Research Clinics Program Epidemiology Committee. Plasma lipid distributions in selected North American populations: the Lipid Research Clinics Program Prevalence Study. Circulation 1979;60:427-39.

40. Nordestgaard B G, Chapman J, Ray K, Bore'n J, Andreotti F, Watts GF, Ginsberg H, Amarenco P, Catapano A, Descamps 


\section{Erwinanto dkk: Pedoman tatalaksana dislipidemia}

OS, Fisher E, Kovanen PT, Kuivenhoven JA, Lesnik P, Masana L, Reiner Z, Taskinen MR, Tokgo“zoglu L, Tybjærg-Hansen A, for the European Atherosclerosis Society Consensus Panel. Lipoprotein(a) as a cardiovascular risk factor: current status. Eur Heart J 2010;31:2844-53.

41. Mora S, Szklo M, Otvos JD, Greenland P, Psaty BM, Goff DC Jr, O'Leary DH, Saad MF, Tsai MY, Sharrett AR. LDL particle subclasses, LDL particle size, and carotid atherosclerosis in the Multi-Ethnic Study of Atherosclerosis (MESA). Atherosclerosis 2007;192:211-7.

42. Jones P H, Davidson MH, Stein EA, Bays HE, McKenney JM, Miller E, Cain VA, Blasetto JW. Comparison of the efficacy and safety of rosuvastatin versus atorvastatin, simvastatin, and pravastatin across doses (STELLAR Trial). Am J Cardiol 2003;92:152-60.

43. The BIP Study Group. Secondary prevention by raising HDL cholesterol and reducing triglycerides in patients with coronary artery disease. The Bezafibrate Infarction Prevention (BIP) Study. Circulation 2000;102:21-7.

44. Keech A, Simes RJ, Barter P, Best J, Scott R, Taskinen MR, Forder P, Pillai A, Davis T, Glasziou P, Drury P, Kesa“niemi YA, Sullivan D, Hunt D, Colman P, d'Emden M, Whiting M, Ehnholm C, Laakso M. The FIELD Study Investigators. Effects of long-term fenofibrate therapy on cardiovascular events in 9795 people with type 2 diabetes mellitus (the FIELD study): randomised controlled trial. Lancet 2005;366:1849-61.

45. Jun M, Foote C, Lu J, Patel A, Nicholls SJ, Grobbee DE, Cass A, Chalmers J, Perkovic V. Effects of fibrates on cardiovascular outcomes: a systematic review and meta-analysis. Lancet 2010;375:1875-84.

46. Jones P H, Davidson MH. Reporting rate of rhabdomyolysis with fenofibrate+statin versus gemfibrozil+any statin. Am J Cardiol 2005;95:120-2.

47. Ford E S, Ajani UA, Croft JB, Critchley JA, Labarthe DR, Kottke TE, Giles WH, Capewell S. Explaining the decrease in U.S. deaths from coronary disease, 1980-2000. N Engl J Med 2007;356:2388-98.

48. Mensink R P, Zock PL, Kester ADM, Katan MB. Effects of dietary fatty acids and carbohydrates on the ratio of serum total to HDL cholesterol and on serum lipids and apolipoproteins: a meta-analysis of 60 controlled trials. Am j Clin Nutr 2003;77:1146-55.

49. Harris W S. Omega-6 Fatty Acids and Risk for Cardiovascular Disease : A Science Advisory From the American Heart Association Nutrition Subcommittee of the Council on Nutrition, Physical Activity, and Metabolism. Circulation 2009;119:9027.

50. Denmacker P N, Reijnen IG, Katan MB, Stuyt PM, Stalenhoef AF. Increased removal of remnants of triglyceride-rich lipoproteins on a diet rich in polyunsaturated fatty acids. Eur J Clin
Invest 1991;21:197-203.

51. Zheng C, Khoo C, Furtado J, Ikewaki K, Sacks FM. Dietary monounsaturated fat activates metabolic pathways for triglyceride-rich lipoproteins that involve apolipoproteins $\mathrm{E}$ and C-III. Am j Clin Nutr 2008;99:272-81.

52. Lichtenstein A H, Ausman LM, Jalbert SM, Schaefer EJ. Effects of different forms of dietary hydrogenated fats on serum lipoprotein cholesterol levels. N Engl J Med 1999;340:1933-40.

53. Katan M B, Zock PL, Mensink RP. Trans fatty acids and their effects on lipoproteins in humans. Ann Rev Nutr 1995;15:47393.

54. Ascherio A, Katan MB, Zock PL, Stampfer MJ, Willett WC. Trans fatty acids and coronary heart disease. N Engl J Med 1999;340:1994-8.

55. NCEP Expert Panel on detection evaluation and treatment of high blood cholesterol in adults. Executive summary of the third report of the National Cholesterol Education Program (NCEP) Expert Panel on detection, evaluation and treatment of high blood cholesterol in adults (Adult Treatment Panel III). JAMA 2001;285:2486-97.

56. Brown L, Rosner B, Willet W, Sacks SM. Cholesterol-lowering effects of dietary fiber: a meta-analysis. Am J Clin Nutr 1999;69:30-42.

57. Kodama S, Tanaka S, Saito K, Shu M, Sone Y, Onitake F, Suzuki E, Shimano H, Yamamoto S, Kondo K, Ohashi Y, Yamada N, Sone H. Effect of aerobic exercise training on serum levels of high-density lipoprotein cholesterol: a meta-analysis. Arch Intern Med 2007;167:999-1008.

58. Magkos F, Tsekouras YE, Prentzas KI, Basioukas KN, Matsama SG, Yanni AE, Kavouras SA, Sidossis LS. Acute exercise-induced changes in basal VLDL-triglyceride kinetics leading to hypotriglyceridemia manifest more readily after resistance than endurance exercise. J Appl Physiol 2008;105:1228-36.

59. Tambalis K, Panagiotakos DB, Kavouras SA, Sidossis LS. Responses of blood lipids to aerobic, resistance, and combined aerobic with resistance exercise training: a systematic review of current evidence. Angiology 2009;60:614-32.

60. Kelley G A, Kelley KS. Impact of progressive resistance training on lipids and lipoproteins in adults: a meta-analysis of randomized controlled trials. Prev Med 2009;48:9-19.

61. Couillard C, Despre's JP, Lamarche B, Bergeron J, Gagnon J, Leon AS, Rao DC, Skinner JS, Wilmore JH, Bouchard C. Effects of endurance exercise training on plasma HDL cholesterol levels depend on levels of triglycerides: evidence from men of the Health, Risk Factors, Exercise Training and Genetics (HERITAGE) Family Study. Arterioscler Thromb Vasc Biol 2001;21:1226-32.

62. Kraus W E, Houmard JA, Duscha BD, Knetzger KJ, Wharton MB,, McCartney JS BC, Henes S, Samsa GP, Otvos JD, Kulkarni KR, Slentz C. Effects of the amount and intensity of 


\section{Jurnal Kardiologi Indonesia}

exercise on plasma lipoproteins. N Engl J Med 2002;347:148392.

63. Duncan G E, Anton SD, Sydeman SJ, Newton RL Jr, Corsica JA, Durning PE, Ketterson TU, Martin AD, Limacher MC, Perri MG. Prescribing exercise at varied levels of intensity and frequency: a randomized trial. Arch Intern Med 2005;165:23629.

64. Durstine J L, Summer AC. Physical Activity, Exercise, Blood Lipids, and Lipoproteins. In Moffatt JR, Stamford B, Eds. Lipid Metabolism and Health. Boca Raton: CRC Press 2006.

65. Pischon T, Boeing H, Hoffmann K, Bergmann M, Schulze MB, Overvad K, Van der Schouw YT, Spencer E, Moons KGM, Tjønneland A, Halkjaer J, Jensen MK, Stegger J, ClavelChapelon F, Boutron-Ruault MC, Chajes V, Linseisen J, Kaaks R, Trichopoulou A, Trichopoulos D, Barnia C, Sieri S, Palli D, Tumino R, Vineis P, Panico S, Peeters PHM, May AM, Buenode-Mesquita HB, van Duijnhoven FJB, Hallmans G, Weinehall L, Manjer J, Hedblad B, Lund E, Agudo A, Arriola L, Barricarte A, Navarro C, Martinez C, Quirós JR, Key T, Bingham S, Khaw KT, Boffetta P, Jenab M, Ferrari P, Riboli E. General and Abdominal Adiposity and Risk of Death in Europe. N Engl J Med 2008;359:2105-20.

66. Inoue S. The Asia-Pacific Perspective: Redefining Obesity and Its Treatment. WHO International Obesity Task Force 2000.

67. Prospective study collaboration. Body-mass index and causespecific mortality in 900000 adults: collaborative analyses of 57 prospective studies. Lancet 2009;373.

68. Dattilo A M, Kris-Etherton PM. Effects of weight reduction on blood lipids and lipoproteins: a meta-analysis. Am j Clin Nutr 1992; $56: 320-8$

69. The Look AHEAD Research Group. Cardiovascular Effects of Intensive Lifestyle Intervention in Type 2 Diabetes. N Engl J Med 2013.

70. Maeda K, Noguchi Y, Fukui T. The effects of cessation from cigarette smoking on the lipid and lipoprotein profiles: a metaanalysis. Prev Med 2003;37:283-90.

71. Stone N J. Secondary causes of hyperlipidemia. Med Clin North Am 1994;78:117-41.

72. Chait A, Brunzell JD. Acquired hyperlipidemia (secondary dyslipoproteinemias). Endocrinol Metab Clin North Am 1990;19:259-78.

73. Hendriks H F, Weststrate JA, van Vliet T, Meijer GW. Spreads enriched with three different levels of vegetable oil sterols and the degree of cholesterol lowering in normocholesterolaemic and mildly hypercholesterolaemic subjects. Eur J Clin Nutr 1999;53:319-27.

74. Katan M B, Grundy SM, Jones P, Law M, Miettinen T, Paoletti R. Efficacy and safety of plant stanols and sterols in the management of blood cholesterol levels. Mayo Clin Proc 2003;78:96578.
75. Abumweis S S, Barake R, Jones PJ. Plant sterols/stanols as cholesterol lowering agents: a meta-analysis of randomized controlled trials. Food Nutr Res 2008;52.

76. Dewell A, Hollenbeck PL, Hollenbeck CB. A critical evaluation of the role of soy protein and isoflavone supplementation in the control of plasma cholesterol concentrations. J Clin Endocrinol Metab 2006;91:772-80.

77. Jenkins D J, Kendall CW, Vidgen E, Mehling CC, Parker T, Seyler H, Faulkner D, Garsetti M, Griffin LC, Agarwal S, Rao AV, Cunnane SC, Ryan MA, Connelly PW, Leiter LA, Vuksan $\mathrm{V}$, Josse R. The effect on serum lipids and oxidized low-density lipoprotein of supplementing self-selected low-fat diets with soluble fiber, soy, and vegetable protein foods. Metabolism 2000;49:67-72.

78. U.S. Department of Health and Human Services. Food and Drug Administration. Food labeling: health claims; soluble fiber from certain foods and coronary heart disease: final rule. Federal Register 1998;63:8103-21.

79. U.S. Department of Health and Human Services. Food and Drug Administration. Food labeling: health claims; soluble fiber from certain foods and coronary heart disease: proposed rule. Federal Register 1997;62:28234-45.

80. Rideout T C, Harding SV, Jones PJ, Fan MZ. Guar gum and similar soluble fibers in the regulation of cholesterol metabolism: current understandings and future research priorities. Vasc Health Risk Manag 2008;4:1023-33.

81. Harris W S. n-3 Fatty acids and serum lipoproteins: human studies. Am j Clin Nutr 1997;65 (suppl.):1645S-54S.

82. Prasad K. Flaxseed and cardivascular health. J Cardiovasc Pharmacol 2009;54:369-77.

83. Kromhout D, Giltay EJ, Geleijnse JM for the Alpha Omega Trial Group. n-3 Fatty acids and cardiovascular events after myocardial infarction. N Engl J Med 2010;363:2015-26.

84. Hooper L, Thompson RL, Harrison RA, Summerbell CD, Ness AR, Moore HJ, Worthington HV, Durrington PN, Higgins JPT, Capps NE, Riemersma RA, Ebrahim SBJ, Davey Smith G. Risks and benefits of omega 3 fats for mortality, cardiovascular disease, and cancer: systematic review. BMJ 2006;332:752-60.

85. Yokoyama M OH, Matsuzaki M, Matsuzawa Y, Saito Y, Oikawa S, Sasaki J, Hishida H, Itakura H, Kita T, Kitabatake A, Nakaya N, Sakata T, Shimada K, Shirato K. Effects of eicosapentaenoic acid on major coronary events in hypercholesterolaemic patients (JELIS): a randomised openlabel, blinded endpoint analysis. Lancet 2007;369:1090-8.

86. Endo A. The discovery and development of HMG-CoA reductase inhibitors. J Lipid Res 1992;33:1569-82.

87. Bilheimer D W, Grundy SM, Brown MS, Goldstein JL. Mevinolin and colestipol stimulate receptor-mediated clearance of low density lipoprotein from plasma in familial hypercholesterolemia heterozygotes. Proc Natl Acad Sci USA 1983;80:4124-8. 
88. Barter P J, Brandrup-Wognsen G, Palmer MK, Nicholls SJ Effect of statins on HDL-C: a complex process unrelated to changes in LDL-C: analysis of the VOYAGER Database. J Lipid Res 2010;51:1546-53.

89. Long-Term Intervention with Pravastatin in Ischaemic Disease (LIPID) Study Group. Prevention of cardiovascular events and death with pravastatin in patients with coronary heart disease and a broad range of initial cholesterol levels. $\mathrm{N}$ Engl J Med 1998;339:1349-57.

90. Downs J R, Clearfield M, Weis S, Whitney E, Shapiro DR, Beere PA, Langendorfer A, Stein EA, Kruyer W, Gotto AM Jr, for the AFCAPS/TexCAPS Research Group. Primary prevention of acute coronary events with lovastatin in men and women with average cholesterol levels: results of AFCAPS/TexCAPS. JAMA 1998;279:1615-22.

91. Shepherd J, Cobbe SM, Ford I, Isles CG, Lorimer AR, Macfarlane PW, McKillop JH, Packard CJ, for the West of Scotland Coronary Prevention Study Group. Prevention of coronary heart disease with pravastatin in men with hypercholesterolemia. $\mathrm{N}$ Engl J Med 1995;333:1301-7.

92. Scandinavian Simvastatin Survival Study Group. Randomised trial of cholesterol lowering in 4444 patients with coronary heart disease: the Scandinavian Simvastatin Survival Study (4S). Lancet 1994;344:1383-9.

93. Sacks F M, Pfeffer MA, Moye LA, Rouleau JL, Rutherford JD, Cole TG, Brown L, Warnica JW,Arnold JMO, Wun C-C, Davis BR, Braunwald E, for the Cholesterol and Recurrent Events Trial Investigators. The effect of pravastatin on coronary events after myocardial infarction in patients with average cholesterol levels. N Engl J Med 1996;335:1001-9.

94. U.S. Department of Health and Human Services. Food and Drug Administration. FDA Drug Safety Communication: New restrictions, contraindications, and dose limitations for Zocor (simvastatin) to reduce the risk of muscle injury. 2011.

95. Nelson R G, Tuttle KR, Bilous RW, Gonzalez-CampoyJM, Mauer M, Molitch ME, Sharma K, Judith Fradkin E, Narva AS. KDOQI Clinical Practice Guideline For Diabetes and CKD: 2012 Update. Am J Kidney Dis 2012;60:850-86.

96. Tyroler H A. Cholesterol and cardiovascular disease. An overview of Lipid Research Clinics (LRC) epidemiologic studies as background for the LRC Coronary Primary Prevention Trial. Am J Cardiol 1984;54:14C-9C.

97. Canner P L, Berge KG, Wenger NK, Stamler J, Friedman L, Prineas RJ, Friedewald W. Fifteen year mortality in Coronary Drug Project patients: longterm benefit with niacin. J Am Coll Cardiol 1986;8:1245-55.

98. Pasternak R C, Smith Jr SC, Bairey-Merz CN, Grundy SM, Cleeman JI, Lenfant C. ACC/AHA/NHLBI Clinical Advisory on the Use and Safety of Statins. J Am Coll Cardiol 2002;40:56772.
99. Hsu I, Spinler SA, Johnson NE. Comparative evaluation of the safety and efficacy of HMG-CoA reductase inhibitor monotherapy in the treatment of primary hypercholesterolemia. Ann Pharmacother 1995;29:743-59.

100. U.S. Department of Health and Human Services. Food and Drug Administration. Statin Drugs - Drug Safety Communication: Class Labeling Change. 2012.

101. Sattar N, Preiss D, Murray HM, Welsh P, Buckley BM, de Craen AJ, Seshasai SR,McMurray JJ, Freeman DJ, Jukema JW, Macfarlane PW, Packard CJ, Stott DJ, Westendorp RG, Shepherd J, Davis BR, Pressel SL, Marchioli R, Marfisi RM,Maggioni AP, Tavazzi L, Tognoni G, Kjekshus J, Pedersen TR, Cook TJ, Gotto AM, Clearfield MB, Downs JR, Nakamura H, Ohashi Y, Mizuno K,Ray KK, Ford I. Statins and risk of incident diabetes: a collaborative meta-analysis of randomized statin trials. Lancet 2010:735-42.

102. Ford I, Murray H, Packard CJ, Shepherd J, McFarlane PW, Cobbe SM, for the West of Scotland Coronary Prevention Study Group. Long-Term Follow-up of the West of Scotland Coronary Prevention Study. N Engl J Med 2007;357:1477-86.

103. Reckless JP D, Henry P, Pomykaj T, Lim ST, Massaad R, Vandormael K, Johnson-Levonas AO, Lis K, Brudi P, Allen C. Lipid-altering efficacy of ezetimibe/simvastatin $10 / 40 \mathrm{mg}$ compared with doubling the statin dose in patients admitted to the hospital for a recent coronary event: the INFORCE study. Int J Clin Pract 2008;62:539-54.

104. Rossebø A B, Pedersen TR, Boman K, Brudi P, Chambers JB, Egstrup K, Gerdts E, Gohlke-Ba“rwolf C, Holme I, Kesa"niemi YA, Malbecq W, Nienaber CA, Ray S, Skjaerpe T, Wachtell K, Willenheimer R. SEAS Investigators. Intensive lipid lowering with simvastatin and ezetimibe in aortic stenosis. $\mathrm{N}$ Engl J Med 2008;359:1343-56.

105. SHARP Collaborative Group. Study of Heart and Renal Protection (SHARP): randomized trial to assess the effects of lowering low-density lipoprotein cholesterol among 9,438 patients with chronic kidney disease. Am Heart J 2010;160:785-94.

106. Florentin M, Liberopoulos EN, Elisaf MS. Ezetimibe-associated adverse effects: what the clinician needs to know. Int J Clin Pract 2008;62:88-96.

107. Peto R, Emberson J, Landray M, Baigent C, Collins R, Clare R, Califf R. Analyses of Cancer Data from Three Ezetimibe Trials. N Engl J Med 2008;359:1357-66.

108. Cannon C P, Giugliano RP, Blazing MA, Harrington RA, Peterson JL, Sisk CMC, Strony J, Musliner TA, McCabe CH, Veltri E, Braunwald E, Califf RM, for the IMPROVE-IT Investigators. Rationale and design of IMPROVE-IT (IMProved Reduction of Outcomes: Vytorin Efficacy International Trial): Comparison of ezetimbe/simvastatin versus simvastatin monotherapy on cardiovascular outcomes in patients with acute coronary syndromes. Am Heart J 2008;156:826-32. 


\section{Jurnal Kardiologi Indonesia}

109. Knopp R H. Drug treatment of lipid disorders. N Engl J Med 1999;341:498-511.

110. The ACCORD Study Group. Effects of combination lipid therapy in type 2 diabetes mellitus. N Engl J Med 2010;362:156374.

111. Davidson M H, Armani A, McKenney JM, Jacobson TA. Safety considerations with fibrate therapy. Am J Cardiol 2007;99:3C$18 \mathrm{C}$.

112. Knopp R H, Ginsberg J, Albers JJ, Hoff C, Ogilvie JT, Warnick GR, Burrows E, Retzlaff B, Poole M. Contrasting effects of unmodified and time-release forms of niacin on lipoproteins in hyperlipidemic subjects: clues to mechanism of action of niacin. Metabolism 1985;34:642-50.

113. Grundy S M, Mok HYI, Zech L, Berman M. Influence of nicotinic acid on metabolism of cholesterol and triglycerides in man. J Lipid Res 1981;22:24-36.

114. Knopp R H, Alagona P, Davidson M, Goldberg AC, Kafonek SD, Kashyap M, Sprecher D, Superko HR, Jenkins S, Marcovina $S$. Equivalent efficacy of a time-release form of niacin (Niaspan) given once-a-night vs. plain niacin in the management of hyperlipidemia. Metabolism 1998;47:1097-104.

115. Kamanna V S, Kashyap ML. Mechanism of action of niacin. Am J Cardiol 2008;101:20B-6B.

116. Thrive Study. http://www.thrivestudy.org/press_release.htm.

117. Barter P J, Brewer HB Jr, Chapman MJ, Hennekens CH, Rader DJ, Tall AR. Cholesteryl ester transfer protein: a novel target for raising HDL and inhibiting atherosclerosis. Arterioscler Thromb Vasc Biol 2003;23:160-7.

118. Bloomfield D, Carlson GL, Sapre A, Tribble D, McKenney JM, Littlejohn III TW, III, Sisk CM, Mitchel Y, Pasternak RC. Efficacy and safety of the cholesteryl ester transfer protein inhibitor anacetrapib as monotherapy and coadministered with atorvastatin in dyslipidemic patients. Am Heart J 2009; 157:35260. e2.

119. Reiner Z. Combined therapy in the treatment of dyslipidemia. Fundam Clin Pharmacol 2010;24:19-28.

120. Huijgen R, Abbink EJ, Bruckert E, Stalenhoef AF, Imholz BP, Durrington PN, Trip MD, Eriksson M, Visseren FL, Schaefer JR, Kastelein JJ; Triple Study Group. Colesevelam added to combination therapy with a statin and ezetimibe in patients with familial hypercholesterolemia: a 12-week multicenter, randomized, double-blind, controlled trial. Clin Ther 2010;32:61525.

121. Grundy S M, Vega GL, Yuan Z, Battisti WP, Brady WE, Palmisano J. Effectiveness and tolerability of simvastatin plus fenofibrate for combined hyperlipidaemia (the SAFARI trial). Am J Cardiol 2005;95:462-8.

122. McKenney J M, Jones PH, Bays HE, Knopp RH, Kashyap ML, Ruoff GE, McGovern ME. Comparative effects on lipid levels of combination therapy with a statin and extended-release niacin or ezetimibe versus a statin alone (the COMPELL study). Atherosclerosis 2007;192:432-7.

123. DeMott K, Nherera L, Shaw EJ, Minhas R, Humphries SE, Kathoria M, Ritchie G,Nunes V, Davies D, Lee P, McDowell I, Neil A, Qureshi N, Rowlands P, Seed M, Stracey H, Thorogood M, Watson M. . Clinical guidelines and evidence review for familial hypercholesterolaemia: the identification and management of adults and children with familial hypercholesterolaemia. National Collaborating Centre for Primary Care and Royal College of General Practitioners 2008.

124. Veenkamp M S, de Graaf J, Bredie SJ, Hendriks JC, Demacker PN, Stalenhoef AF. . Diagnosis of familial combined hyperlipidemia based on lipid phenotype expression in 32 families: results of a 5-year follow-up study. Arterioscler Thromb Vasc Biol 2002;22:274-82.

125. Gaddi A, Cicero AFG, Odoo FO, Poli AA, Paoletti R. Practical guidelines for familial combined hyperlipidemia diagnosis: an up-date. . Vasc Health Risk Manag 2007;3:877-86.

126. Kostis W J, Cheng JQ, Dobrzynski JM, Cabrera J, Kostis JB. . Meta-Analysis of Statin Effects in Women Versus Men. J Am Coll Cardiol 2012;59:572-82.

127. Lewis S J, Moye LA, Sacks FM, Johnstone DE, Timmis G, Mitchell J, Limacher M, Kell S, Glasser SP, Grant J, Davis BR, Pfeffer MA, Braunwald E. for the CARE investigators Effect of pravastatin on cardiovascular events in older patients with myocardial infarction and cholesterol levels in the average range. Ann Intern Med 1998;129:681-9.

128. Miettinen T A, Pyörälä K, Olsson AG, Musliner TA, Cook TJ, Faergeman O, Berg K, Pedersen T, Kjekshus J. Cholesterol lowering therapy in women and elderly patients with myocardial infarction or angina pectoris: findings from the Scandinavian Simvastatin Survival Study (4S). Circulation 1997;96:4211-8.

129. Shepherd J, Blauw GJ, Murphy MB, Bollen EL, Buckley BM, Cobbe SM, Ford I, Gaw A, Hyland M, Jukema JW, Kamper AM, Macfarlane PW, Meinders AE, Norrie J, Packard CJ, Perry IJ, Stott DJ, Sweeney BJ, Twomey C, Westendorp RG; PROSPER Study Group. . PROspective Study of Pravastatin in the Elderly at Risk. Pravastatin in elderly individuals at risk of vascular disease (PROSPER): a randomised controlled trial. Lancet 2002;360:1623-30.

130. Alberti K G, Eckel RH, Grundy SM, Zimmet PZ, Cleeman JI, Doanto KA, Fruchart J-C, James PT, Loria CM, Smith SC. Harmonizing the metabolic syndrome: a joint interim statement of the International Diabetes Federation Task Force on Epidemiology and Prevention; National Heart, Lung, and Blood Institute; American Heart Association; World Heart Federation; International Atherosclerosis Society; and International Association for the Study of Obesity. Circulation 2009;120:1640-5.

131. Hillier T A, Rizzo JH, Pedula KL, Cauley JA, Schwartz AV, Ensrud KE, Browner WS. . Increased Mortality Associated 
With the Metabolic Syndrome in Older Women With Diabetes. Diabetes Care 2005;28:2258-60.

132. Mottillo S, Filion KB, Genest J, Joseph L, Pilote L, Poirier P, Rinfret S, Schiffrin EL, Eisenberg MJ. . The metabolic syndrome and cardiovascular risk. A systematic review and meta-analysis. J Am Coll Cardiol 2010;56:1113-32.

133. Adiels M, Olofsson S-O, Taskinen M-R, Bore'n J. . Overproduction of very low-density lipoproteins is the hallmark of the dyslipidaemia in the metabolic syndrome. Arterioscler Thromb Vasc Biol 2008;28:1225-36.

134. Scott R, O'Brien R, Fulcher G, Pardy C, D'Emden M, Tse D, Taskinen M-R, Ehnholm C, Keech A. . Effects of fenofibrate treatment on cardiovascular disease risk in 9,795 individuals with type 2 diabetes and various components of the metabolic syndrome. Diabetes Care 2009;32:493-8.

135. Ilanne-Parikka P, Eriksson JG, Lindstrom J, Peltonen M, Aunola S, Hamalainen H, Keinanen-Kiukaanniemi S, Laakso M, Valle TT, Lahtela J, Uusitupa M, Tuomilehto J. Effect of lifestyle intervention on the occurrence of metabolic syndrome and its components in the Finnish diabetes prevention study. Diabetes Care 2008;31:805-7.

136. Colhoun H M, Betteridge DJ, Durrington PN, Hitman GA, Neil HA, Livingstone SJ, Thomason MJ, Mackness MI, Charlton-Menys V, Fuller JH; CARDS Investigators. . Primary prevention of cardiovascular disease with atorvastatin in type 2 diabetes in the Collaborative Atorvastatin Diabetes Study (CARDS): multicentre randomised placebo-controlled trial. Lancet 2004;364:685-96.

137. Adolescent type 1 Diabetes cardio-renal Interventional Trial Research Group. Adolescent type 1 Diabetes Cardio-renal Intervention Trial (AdDIT). . BMC Pediatr 2009;9:79.

138. Kasiske B, Cosio FG, Beto J, Chavers B, Grimm Jr R, Levin A, Masri B, Parekh R, Wanner C, Wheeler D, Wilson W. . K/ DOQI Clinical Practice Guidelines for Managing Dyslipidemias in Chronic Kidney Disease. Am J Kidney Dis 2003;41:S1S91.

139. Fellström B C, Jardine AG, Schmieder RE, Holdaas H, Bannister K, Beutler J, Chae DW, Chevaile A, Cobbe SM, GönhagenRiska C, De Lima JJ, Lins R, Mayer G, McMahon AW, Parving HH, Remuzzi G, Samuelsson O, Sonkodi S,Sci D, Süleymanlar G, Tsakiris D, Tesar V, Todorov V, Wiecek A, Wüthrich RP, Gottlow M, Johnsson E, Zannad F; AURORA Study Group. . Rosuvastatin and cardiovascular events in patients undergoing hemodialysis. N Engl J Med 2009;360:1395-407.

140. Wanner C, Krane V, März W, Olschewski M, Mann JF, Ruf G, Ritz E; German Diabetes and Dialysis Study Investigators. . Atorvastatin in patients with type 2 diabetes mellitus undergoing hemodialysis. N Engl J Med 2005;353:238-48.

141. National Kidney Foundation. K/DOQI clinical practice guidelines for chronic kidney disease: Evaluation, classification, and stratification. Am J Kidney Dis 2002;39:S1-S266.

142. Benfante R, Yano K, Hwang LJ, Curb JD, Kagan A, Ross W. . Elevated serum cholesterol is a risk factor for both coronary heart disease and thromboembolic stroke in Hawaiian Japanese men. Implications of shared risk. Stroke 1994;25:814-20.

143. Iso H, Jacobs, Jr. DR, Wentworth D, Neaton JD, Cohen JD. . Serum Cholesterol Levels and Six-Year Mortality from Stroke in 350,977 Men Screened for the Multiple Risk Factor Intervention Trial. . N Engl J Med 1989;320:904-10.

144. Engström G, Lind P, Hedblad B, Stavenow L, Janzon L, Lindgärde F. . Effects of Cholesterol and Inflammation-Sensitive Plasma Proteins on Incidence of Myocardial Infarction and Stroke in Men. Circulation 2002;105:2632-7.

145. Prospective Studies Collaboration. Cholesterol, diastolic blood pressure, and stroke: 13000 strokes in 450000 people in 45 prospective cohorts. Lancet 1995;346:1647-53.

146. Suh I, Jee SH, Kim HC, Nam CM, Kim IS, Appel LJ. . Low serum cholesterol and haemorrhagic stroke in men: Korea Medical Insurance Corporation Study. Lancet 2001;357:922-25.

147. LaRosa J C, Grundy SM, Waters DD, Shear C, Barter P, Fruchart JC, Gotto AM, Greten H, Kastelein JJ, Shepherd J, Wenger NK; Treating to New Targets (TNT) Investigators. . Intensive lipid lowering with atorvastatin in patients with stable coronary disease. . N Engl J Med 2005;352:1425-35.

148. Amarenco P, Labreuche J. Lipid management in the prevention of stroke: review and updated meta-analysis of statins for stroke prevention. . Lancet Neurol 2009;8:453-63.

149. Byington R P, Davis BR, Plehn JF, White HD, Baker J, Cobbe SM, Shepherd J. Reduction of stroke events with pravastatin: the Prospective Pravastatin Pooling (PPP) project. . Circulation 2001;103:387-92.

150. The Stroke Prevention by Aggressive Reduction in Cholesterol Levels (SPARCL) Investigators. High-dose atorvastatin after stroke or transient ischemic attack. N Engl J Med 2006;355:54959.

151. Ray K K, Cannon CP, McCabe CH, Cairns R, Tonkin AM, Sacks FM, Jackson G, Braunwald E; PROVE IT-TIMI 22 Investigators. Early and late benefits of high dose atorvastatin in patients with acute coronary syndromes: results from the PROVE IT-TIMI 22 trial. J Am Coll Cardiol 2005;46:140510.

152. Lee K H, Jeong MH, Kim HM, Ahn Y, Kim JH, Chae SC, Kim YJ, Hur SH, In Whan Seong IW, Hong TJ, Choi DH, Cho MC, Kim CJ, Seung KB, Chung WS, Jang YS, MD, Rha SW, Bae JH, Cho JW, Park SJ, KAMIR (Korea Acute Myocardial Infarction Registry) Investigators. Benefit of early statin therapy in patients with acute myocardial infarction who have extremely low low-density lipoprotein cholesterol. J Am Coll Cardiol 2011;58:1664-71.

153. GISSI-Prevenzione Investigators. Dietary supplementation 
with $\mathrm{n}-3$ polyunsaturated fatty acids and vitamin $\mathrm{E}$ after myocardial infarction: results of the GISSIprevenzione trial. Lancet 1999;354:447-55.

154. Di Sciascio G, Patti G, Pasceri V, Gaspardone A, Colonna G, Montinaro A. Efficacy of atorvastatin reload in patients on chronic statin therapy undergoing percutaneous coronary intervention: results of the ARMYDA-RECAPTURE (Atorvastatin for Reduction of MYocardial Damage during Angioplasty) randomized trial. J Am Coll Cardiol 2009;54:558-65.

155. Pasceri V, Patti G, Nusca A, Pristipino C, Richich Gi, Di Sciascio G, on behalf of the ARMYDA Investigators. Randomized Trial of Atorvastatin for Reduction of Myocardial Damage During
Coronary Intervention Results From the ARMYDA (Atorvastatin for Reduction of Myocardial Damage during Angioplasty) Study. Circulation 2004;110:674-8.

156. Winchester D E, Wen X, Xie L, Bavry AA. Evidence of preprocedural statin therapy: a meta-analysis of randomized trials. J Am Coll Cardiol 2010;56:1099-109.

157. Briguori C, Visconti G, Focaccio A, Golia B, Chieffo A, Castelli A, Mussardo M, Montorfano M, Ricciardelli B, Colombo A. Novel approaches for preventing or limiting events (NAPLES) II trial impact of a single high loading dose of atorvastatin on periprocedural myocardial infarction. J Am Coll Cardiol 2009;54:2157-63. 